\title{
Carbon dioxide fluxes over an ancient broadleaved deciduous woodland in southern England
}

\author{
M. V. Thomas ${ }^{1}$, Y. Malhi ${ }^{1}$, K. M. Fenn ${ }^{1,2}$, J. B. Fisher ${ }^{1}$, M. D. Morecroft ${ }^{2, *}$, C. R. Lloyd ${ }^{2}$, M. E. Taylor ${ }^{2}$, and \\ D. D. $\mathrm{McNeil}^{2}$ \\ ${ }^{1}$ Environmental Change Institute, School of Geography and the Environment, University of Oxford, Oxford, UK \\ ${ }^{2}$ Centre for Ecology \& Hydrology, Wallingford, UK \\ * current address: Natural England, Winchester, UK
}

Received: 12 April 2010 - Published in Biogeosciences Discuss.: 21 May 2010

Revised: 1 June 2011 - Accepted: 6 June 2011 - Published: 21 June 2011

\begin{abstract}
We present results from a study of canopyatmosphere fluxes of carbon dioxide from 2007 to 2009 above a site in Wytham Woods, an ancient temperate broadleaved deciduous forest in southern England. Gapfilled net ecosystem exchange (NEE) data were partitioned into gross primary productivity (GPP) and ecosystem respiration $\left(R_{\mathrm{e}}\right)$ and analysed on daily, monthly and annual timescales. Over the continuous 24 month study period annual GPP was estimated to be $21.1 \mathrm{MgC} \mathrm{ha}^{-1} \mathrm{yr}^{-1}$ and $R_{\mathrm{e}}$ to be $19.8 \mathrm{Mg} \mathrm{Cha}^{-1} \mathrm{yr}^{-1}$; net ecosystem productivity (NEP) was $1.2 \mathrm{MgCha}^{-1} \mathrm{yr}^{-1}$. These estimates were compared with independent bottom-up estimates derived from net primary productivity (NPP) and flux chamber measurements recorded at a plot within the flux footprint in 2008 (GPP = $26.5 \pm 6.8 \mathrm{MgCha}^{-1} \mathrm{yr}^{-1}, R_{\mathrm{e}}=24.8 \pm 6.8 \mathrm{MgCha}^{-1} \mathrm{yr}^{-1}$, biomass increment $=\sim 1.7 \mathrm{MgCha}^{-1} \mathrm{yr}^{-1}$ ). Over the two years the difference in seasonal NEP was predominantly caused by changes in ecosystem respiration, whereas GPP remained similar for equivalent months in different years. Although solar radiation was the largest influence on daily values of $\mathrm{CO}_{2}$ fluxes $\left(R^{2}=0.53\right.$ for the summer months for a linear regression), variation in $R_{\mathrm{e}}$ appeared to be driven by temperature. Our findings suggest that this ancient woodland site is currently a substantial sink for carbon, resulting from continued growth that is probably a legacy of past management practices abandoned over 40 years ago. Our GPP and $R_{\mathrm{e}}$ values are generally higher than other broadleaved temperate deciduous woodlands and may represent the influence of the UK's maritime climate, or the particular species composition of this site. The carbon sink value of Wytham Woods
\end{abstract}

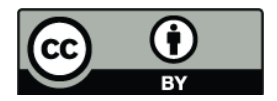

Correspondence to: Y. Malhi (yadvinder.malhi@ouce.ox.ac.uk) supports the protection and management of temperate deciduous woodlands (including those managed for conservation rather than silvicultural objectives) as a strategy to mitigate atmospheric carbon dioxide increases.

\section{Introduction}

Forests are integral in climate change debates, with studies estimating deforestation to account for approximately 12 $15 \%$ of recent annual global carbon dioxide $\left(\mathrm{CO}_{2}\right)$ emissions (van der Werf et al., 2009). Sequestration of $\mathrm{CO}_{2}$ from the atmosphere from photosynthesis and the subsequent assimilation of carbon into above and below ground biomass partially offset anthropogenic emissions of $\mathrm{CO}_{2}$ (Janssens et al., 2003). The global terrestrial carbon sink was estimated at $2.7 \mathrm{Pg} \mathrm{Cyr}^{-1}$ for 2000 to 2006 - equivalent to approximately $30 \%$ of total anthropogenic emissions during this period (Canadell et al., 2007). Increasing global interest in the potential of terrestrial ecosystems such as forests to slow rises in $\mathrm{CO}_{2}$ levels has led to a rise in research to quantify both terrestrial carbon stocks and factors influencing temporal and spatial variation in carbon uptake.

Eddy covariance provides a direct measurement of $\mathrm{CO}_{2}$ fluxes (net ecosystem exchange, NEE) between the atmosphere and forest vegetation on scales of $\sim 1 \mathrm{~km}^{2}$ (Baldocchi et al., 1988). The instrumentation measures the covariance between fluctuations in vertical wind velocity (in the form of turbulent eddies) and the mixing ratio of $\mathrm{CO}_{2}$. In micrometeorological convention, negative flux values represent a net loss of $\mathrm{CO}_{2}$ from the atmosphere to the vegetation and thus assimilation of carbon through photosynthesis. Positive values represent transfer of $\mathrm{CO}_{2}$ to the atmosphere through

Published by Copernicus Publications on behalf of the European Geosciences Union. 
both autotrophic and heterotrophic respiration. By providing rapid continuous estimates of NEE over a given area, and thus vital information regarding how local environmental conditions can affect rates of carbon exchange (Urbanski et al., 2007), eddy covariance can both enhance and validate stock-based estimates of carbon budgets (Curtis et al., 2002). There are over 400 flux research sites worldwide and a global network of collaborating regions, FLUXNET, which assimilates information from research sites over a wide range of biomes (Baldocchi, 2008).

Research employing the eddy covariance technique has been undertaken in temperate deciduous forests across the globe, providing useful information on carbon storage (Granier et al., 2000; Curtis et al., 2002; Knohl et al., 2003), partitioning of forest carbon fluxes (Misson et al., 2007), the impacts of climate change (Urbanski et al., 2007), weather anomalies and seasonal cycles (Saigusa et al., 2008). It has also clarified the impacts of stand age upon carbon sequestration (Wirth et al., 2002; Knohl et al., 2003; Paw U et al., 2004; Amiro et al., 2006; Luyssaert et al., 2008), with findings challenging the traditional ecological paradigm that mature forests no longer achieve manifest net sequestration of atmospheric $\mathrm{CO}_{2}$ (Jarvis et al., 1989). However, there are still many questions regarding controls on carbon sequestration, and a requirement to provide accurate estimates to be used to parameterise and/or validate ecosystem models.

Here we present results from a two-year study of $\mathrm{CO}_{2}$ fluxes above an ancient deciduous broadleaved woodland in southern England. We aim to quantify absolute magnitudes and temporal changes in gross primary productivity (GPP), ecosystem respiration $\left(R_{\mathrm{e}}\right)$ and net ecosystem productivity (NEP) and assess the driving influences of local meteorology and generate estimates of carbon balance. A companion paper (Fenn et al., submitted) provides a detailed "bottomup" analysis of the components of productivity and ecosystem respiration at this site; comparison of the two studies together provides a more comprehensive description and independent testing of the consistency of our understanding of the carbon cycle at our study site. This work adds to the existing $\mathrm{CO}_{2}$ flux literature by focussing on a woodland in a temperate maritime climate (most reported temperate sites have a more continental climate), and in particular an ancient woodland site where tree cover has never been removed, although substantial human impact has taken place over many centuries.

\section{Methodology}

\subsection{Study site description}

Contained within a loop of the River Thames, Wytham Woods ( $51^{\circ} 46^{\prime} \mathrm{N} 1^{\circ} 20^{\prime} \mathrm{W}$; UK National Grid SP: 460080 ) is a 400 ha predominantly broadleaved deciduous forest, $5 \mathrm{~km}$ northwest of Oxford in southern England (Fig. 1). The site

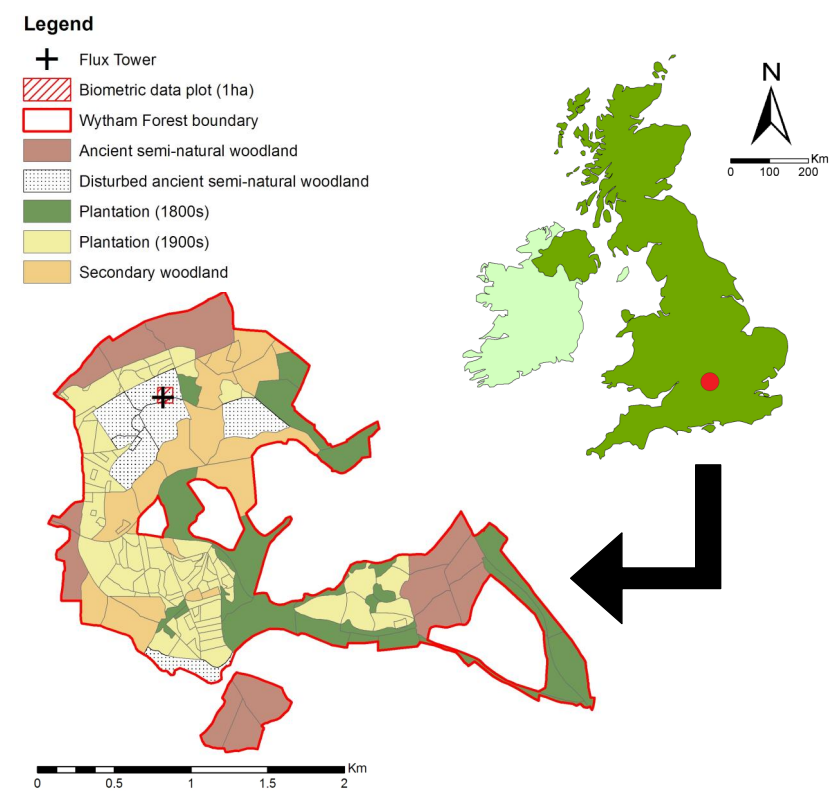

Fig. 1. Study site location in the UK and map of Wytham Woods showing woodland types, location of the flux tower and 1 ha plot used for biometric data collection.

rises to an altitude of $160 \mathrm{~m}$ at the top of Wytham Hill and is surrounded by agricultural land. The Woods mostly fall into the category of W8 Fraxinus excelsior - Acer campestre Mercurialis perennis woodland, in the UK National Vegetation Classification (Rodwell, 1991), with the most common canopy trees species pedunculate oak (Quercus robur), ash (Fraxinus excelsior), sycamore (Acer pseudoplatanus) and beech (Fagus sylvatica), with some conifers in the more recent plantations, understory shrubs such as hazel (Corylus avellana), hawthorn (Crataegus monogyna) and blackthorn (Prunus spinosa), with ground flora including dog's mercury (Mercurialis perennis) and bluebell (Endymion non-scripta). Fuller descriptions are provided in Savill et al. (2010). The climate is typical of the English Midlands region, with average annual precipitation at Wytham around $730 \mathrm{~mm}$ between 1992 and 2009. Meteorological data recorded at Wytham between 1992 and 2009 shows the mean annual temperature to be $10.1^{\circ} \mathrm{C}$. The warmest month of the year, July, averaged temperatures of $16.7^{\circ} \mathrm{C}$ whereas the coldest month, December, averaged $4.4^{\circ} \mathrm{C}$ over this time period. The soils are welldrained at higher elevations and clay-rich and poorly drained at lower altitude.

Owned by Oxford University, Wytham Woods has hosted numerous ecological studies (Savill et al., 2010) and since 1992 has been part of the UK Environmental Change Network (ECN), and since 2008 part of the Smithsonian Global Earth Observatory (SIGEO) Network. Areas of the forest have been broadly classified by Morecroft et al. (2008) into five categories based upon age and species composition (Table 1, Fig. 1), ranging from small areas of 20th century 
Table 1. Classification of woodland in terms of management history at Wytham (adapted from Morecroft et al., 2008).

\begin{tabular}{|c|c|}
\hline $\begin{array}{l}\text { Woodland } \\
\text { classification }\end{array}$ & Description \\
\hline $\begin{array}{l}\text { Undisturbed } \\
\text { ancient } \\
\text { seminatural } \\
\text { woodland }\end{array}$ & $\begin{array}{l}\text { - Woodland hosting continuous forest cover since } \sim 1600 \text {. } \\
\text { - Largely unmanaged for the past } 40-100 \text { years. } \\
\text { - Dominant species are hazel and oak, with ash present. }\end{array}$ \\
\hline $\begin{array}{l}\text { Disturbed } \\
\text { ancient } \\
\text { woodland }\end{array}$ & $\begin{array}{l}\text { - Ancient forest more recently modified by human } \\
\text { management, but which has not been clearfelled. } \\
\text { - Natural regeneration in areas of timber extraction. } \\
\text { - Localised planting, with hazel and oak dominant and } \\
\text { sycamore present. }\end{array}$ \\
\hline $\begin{array}{l}\text { Secondary } \\
\text { woodland }\end{array}$ & $\begin{array}{l}\text { - Former grassland areas, that have naturally reverted to } \\
\text { closed canopy woodland over the last } 200 \text { years. } \\
\text { - Limited localised timber extraction and planting. } \\
\text { - Dominant species are ash and sycamore with some oak. }\end{array}$ \\
\hline $\begin{array}{l}\text { 19th century } \\
\text { plantations }\end{array}$ & $\begin{array}{l}\text { - Former open/grassland areas planted in the } 19 \text { th century. } \\
\text { - Ornamental, widely spaced trees with little management } \\
\text { in recent decades. } \\
\text { - Beech is the dominant species. }\end{array}$ \\
\hline $\begin{array}{l}\text { 20th century } \\
\text { plantations }\end{array}$ & $\begin{array}{l}\text { - Plantations created between } 1950-1970 \text { on grassland } \\
\text { or cleared ancient woodland. } \\
\text { - Plantations consist mainly of oak, beech and } \\
\text { exotic conifers. }\end{array}$ \\
\hline
\end{tabular}

coniferous plantations to serve timber production to ancient semi-natural woodland. The forest immediately surrounding the flux tower is defined as disturbed ancient woodland (Fig. 1), and the canopy is dominated by sycamore, Acer pseudoplatanus, and ash, Fraxinus excelsior. Ancient woodland is defined in the UK as forest that has not been cleared since records began, $\sim 1600$ AD (Peterken, 1981), although they may have been managed for timber extraction, grazing, coppicing or as a source of fuelwood. Ancient woodlands cover approximately $3 \%$ of England's land area, representing around one third of all woodland in England. Their benefits in terms of climate change mitigation, adaptation, biodiversity and recreation are increasingly being recognised by policymakers in the UK (Defra, 2007; Read et al., 2009).

The history of woodland management at Wytham is well documented (Savill et al., 2010) allowing ancient woodland to be divided into what we term "disturbed" and "undisturbed" classifications. Undisturbed ancient woodland has largely remained untouched since the abandonment of coppicing 40-100 years ago (Gibson, 1986). Disturbed areas have also remained largely unmanaged for the last 40 years (Morecroft et al., 2008) as the woods have increasingly been managed on a minimum intervention basis for conservation priorities. One recent active form of management has been regular culling of deer, to encourage forest regeneration.

\subsection{Instrumentation}

Fluxes of energy (sensible heat and latent heat), momentum and $\mathrm{CO}_{2}$ were measured at a height of $25 \mathrm{~m}$ using the eddy covariance technique (Baldocchi et al., 1988). Approximations of the flux footprint (or fetch) were generated using calculations adapted from a model by Schmid and Oke (1990) and are shown in Appendix A (Fig. A1). The flux tower (SP 457 089) is located on the north slope of a moderate a hill, with fetch estimated to vary with atmospheric stability from $\sim 250 \mathrm{~m}$ in very unstable (daytime convective) conditions to over $2 \mathrm{~km}$ in very stable (calm night) conditions. Approximately $90 \%$ of fluxes are estimated to occur within 200 to $600 \mathrm{~m}$ of the tower, predominantly covering areas of disturbed ancient woodland to the southwest (with south-westerly prevailing winds), including the 1 ha plot of biometric data collection described in Fenn et al. (2011). This area is characterised by canopy tree species pedunculate oak (Quercus robur), ash (Fraxinus excelsior) and sycamore (Acer pseudoplatanus). A recent report on Wytham Woods surveying an 18 ha study plot in 2008 and 2009, as part of the Smithsonian Global Earth Observation network, confirms that much of the forest to the south and west is similar oaksycamore-ash dominated woodland as that found in the 1 ha plot around the tower (Butt et al., 2009). Further details on local ecology are summarised in Table 2.

The flux equipment consists of a Solent R2 3D sonic anemometer (Gill Instruments, UK) measuring wind vector components and a LiCOR 7500 open-path infrared gas analyser (IRGA: LiCOR Instruments, Nebraska, USA) measuring atmospheric $\mathrm{CO}_{2}$ concentrations. The sonic anemometer was mounted to ensure complete exposure in all directions. The LiCOR sensor was placed close to the sonic anemometer stem in order to gain the most accurate measurements of wind characteristics and coupled $\mathrm{CO}_{2}$ concentrations, but also slightly below and $0.1 \mathrm{~m}$ to the side of the anemometer's ultrasonic sensor in order to avoid creating flow disturbance. The IRGA sensor was angled slightly to allow surface moisture drainage and prevent direct solar radiation from possibly contaminating readings (Lloyd, 2006).

Measurements were recorded every $0.05 \mathrm{~s}(20 \mathrm{~Hz})$. Raw data outputs from the sonic anemometer and IRGA were recorded on a CR3000 Campbell Scientific Data Logger. Raw data were available from May 2007 to April 2009, on a continuous half-hourly basis with the exception of shortterm periods of data loss. Figure 2 shows the view from the flux tower. Continuous hourly meteorological data including net radiation were recorded from an Automatic Weather Station (Didcot Instruments, UK) located on grassland approximately $840 \mathrm{~m}$ southeast of the tower location. The difference between the vegetation surrounding the weather station and flux tower probably created a small bias in temperature, relative humidity, and net radiation - the air at the weather station sometimes warmer (and less humid) in the day and cooler (and more humid) at the tower (Morecroft et al., 1998). However, the timing of hot or cool events will be the same at both sites. 
Table 2. Study area stand ecological characteristics, based on an 18 ha plot. The tower is located towards the northern end of this plot (summarised from Butt et al., 2009).

\begin{tabular}{ll}
\hline Ecological characteristic & Value \\
\hline Stem density $(>1 \mathrm{~cm} \mathrm{dbh})$ & $1128.2 \mathrm{ha}^{-1}$ \\
Basal area $(>10 \mathrm{~cm} \mathrm{dbh})$ & $31.6 \mathrm{~m}^{2} \mathrm{ha}^{-1}$ \\
Peak leaf area index (LAI) & $7.8 \mathrm{~m}^{2} \mathrm{~m}^{-2}$ \\
Upper canopy mean height & $17 \mathrm{~m}$ \\
Sub-canopy mean height & $6.9 \mathrm{~m}$ \\
Soil texture & Clay $(60 \%)$, \\
& silty clay $(22 \%)$, \\
& clay loam $(15 \%)$, \\
& silty clay loam $(<5 \%)$ \\
Estimated total soil C & $139 \mathrm{Mg} \mathrm{C} \mathrm{ha}^{-1}$ \\
Mean soil carbon content & $5.32 \%(\mathrm{~S} . \mathrm{E} .0 .29)$ \\
Mean soil nitrogen content & $0.395 \%(\mathrm{~S} . \mathrm{E} .0 .02)$ \\
Mean soil C:N ratio & 13.5 \\
Mean soil calcium content $(\mathrm{across})$ & $9630 \mathrm{mg} \mathrm{kg}^{-1}$ \\
soil series and depth 0 to $30 \mathrm{~cm}$ & \\
Mean soil potassium content (across & $218 \mathrm{mg} \mathrm{kg}^{-1}$ \\
soil series and depth 0 to $30 \mathrm{~cm})$ & \\
Mean soil magnesium content (across & $176 \mathrm{mg} \mathrm{kg}^{-1}$ \\
soil series and depth 0 to $30 \mathrm{~cm})$ & \\
Mean soil phosphorus content (across & $78 \mathrm{mg} \mathrm{kg}-1$ \\
soil series and depth 0 to $30 \mathrm{~cm})$ & \\
\hline &
\end{tabular}

\subsection{Flux calculations and corrections}

\subsubsection{Primary raw data processing}

Binary files from 1 May 2007 to 30 April 2009 recorded by the data logger were initially processed using the software tool EdiRe (www.geos.ed.ac.uk/abs/research/ micromet/EdiRe: developed by Edinburgh University). The standard averaging interval (e.g., used by CarboEurope) of $30 \mathrm{~min}$ was used and EdiRe was also run using $60 \mathrm{~min}$ intervals to evaluate the sensitivity of averaging interval on final $\mathrm{CO}_{2}$ flux calculations. Block-averaging was used in the calculation of flux values within these intervals. Within EdiRe a number of calculations and standard corrections for openpath sensors were made following the extraction of raw signals within data files: the three wind velocity components $(u, v$ and $w)$, temperature, water vapour and $\mathrm{CO}_{2} \cdot \mathrm{CO}_{2}$ flux $(F x)$ is essentially equal to the mean product of mean-centred time series of vertical wind speed and mixing ratio of $\mathrm{CO}_{2}$ and was calculated as in Eq. (1):

$F x=\rho \omega^{\prime} x^{\prime}$

Where $\rho=$ the density of dry air, $\omega=$ the vertical wind speed and $x=$ the mixing ratio of $\mathrm{CO}_{2}$. Standard corrections included those for air density effects using Webb-PearmanLeuning (Webb et al., 1980) and vertical wind signal rotation

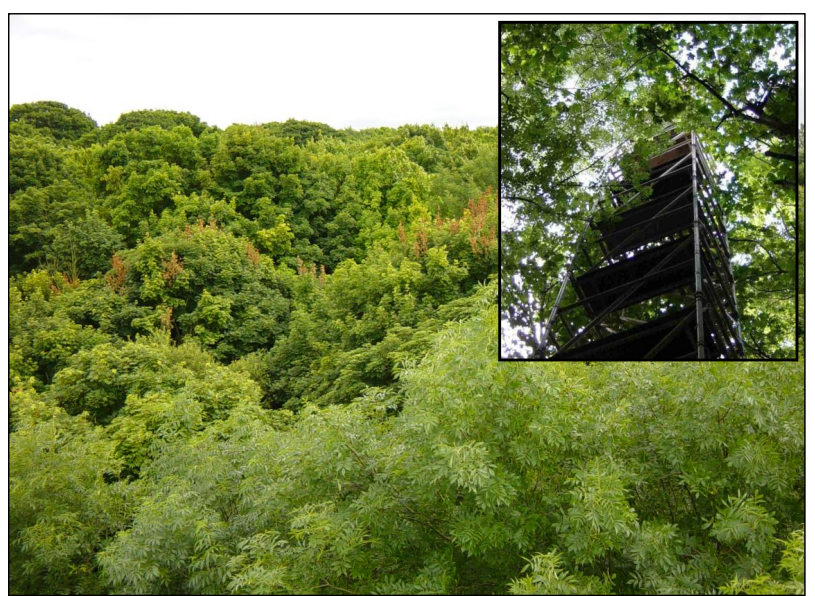

Fig. 2. South-facing aspect from the flux tower, with an insert looking up the flux tower from ground level. Sources: $\mathrm{CEH}$ and author.

to force the mean vertical velocity to zero. Some authors have argued that this approach is only appropriate for level, homogenous terrain. For undulating heterogeneous sites the planar fit method has been employed (Lee et al., 2004), which defines the rotation correction values using an ensemble of wind vectors. However, many studies have found the final flux values generated using "natural" and planar wind fit corrections to be similar (Knohl et al., 2003). Angle of attack corrections specific to Solent sonic anemometers were applied to extend the ability of the Solent to adequately measure wind vectors from outside default limits of \pm 20 degrees from the horizontal. These corrections are now standard, but have resulted in large improvements on the accuracy of flux estimates (Nakai et al., 2006).

\subsubsection{Secondary data processing}

Secondary corrections involved the removal of spurious data, often associated with non-stationary meteorological conditions, and the replacement of these values with more plausible estimates. Such corrections are very much a site-specific task and are far from trivial. Generally, 30-40\% of measurements over one year may be replaced with "gap-filled" values, depending on site-specific characteristics (Moffat et al., 2007; Baldocchi, 2008). These issues may be more acute in fragmented forest such as Wytham, with increased likelihood of advection events from non-forest land or fossil fuel combustion sources. One of the aims of this paper is to explore the sensitivity of final calculated fluxes to data processing procedure. The corrections undertaken are summarised as follows: 


\section{Secondary $\mathrm{CO}_{2}$ flux spike removal}

Despite the low and high-pass filtering undertaken in EdiRe, spikes still occurred in the final $\mathrm{CO}_{2}$ fluxes. We assume that the extreme spikes do not represent natural localised $\mathrm{CO}_{2}$ flux phenomena, but rather non-localised advection events or other non-stationary phenomena. These spikes were removed using a two-tier approach. First, flux values were split into positive and negative groups. Positive values two or more times greater than the standard deviation of all positive values were removed. Negative values two or more times smaller than the standard deviation of all negative values were removed. This had the effect of removing extreme spikes in the dataset and $5 \%$ of the $\mathrm{CO}_{2}$ flux values were deleted. The second stage allowed for more fine-tuned removal of erroneous values. Here, for each month of the year, positive half-hour values were removed that were greater than the average of all $\mathrm{CO}_{2}$ flux values for that month plus the average standard deviation for that month $(x>\bar{x}+\sigma)$ for that half hour period of the day. The opposite was conducted for negative values $(x<\bar{x}-\sigma)$. This removed a further $9 \%$ of all $\mathrm{CO}_{2}$ flux values. This method of spike detection is very similar to that proposed by Papale et al. (2006), and comparison of the two methods produced very similar results.

\section{LE and H flux spike removal}

Erroneous values (spikes) of latent energy flux, LE $(<-100$ or $\left.>800 \mathrm{~W} \mathrm{~m}^{-2}\right)$ and sensible heat flux, $\mathrm{H}(<-150$ or $>$ $500 \mathrm{~W} \mathrm{~m}^{-2}$ ) were removed from the dataset. These may have resulted from strong advection or sensor interference, which also decreases the reliability of associated $\mathrm{CO}_{2}$ flux values, which were concurrently omitted. $7 \%$ of flux data exceeded the above energy thresholds and were deleted. These thresholds represent a compromise between minimising data loss, whilst ensuring as complete an energy balance closure as possible. Variation in the minimum $\mathrm{H}$ threshold in particular had a large impact upon data loss. Energy balance closure is calculated by the following equation:

$\mathrm{SEB}=\frac{(\mathrm{LE}+\mathrm{H}+d S)}{R n}$

Here, SEB $=$ surface energy budget, $R n=$ net radiation, $d S$ $=$ change in heat stored in the canopy and soil. Over a 24$\mathrm{h}$ period $d S \sim 0$, hence a SEB of 1.0 over a 24 -h period would suggest that the eddy covariance method was accounting for all energy fluxes. Although precipitation events are known to interfere with flux sensors (Lloyd, 2006), LE and $\mathrm{H}$ thresholds were implemented rather than targeting precipitation events per se in order to retain the NEE response during wet periods. Furthermore, spikes in the LE and H fluxes were likely to result from such interference from precipitation, and would thus be captured by the spike removal. No adjustments to the flux data were made to compensate for incomplete energy balance closure.

\section{Negative night-time fluxes}

Initial analysis of processed data post-spike removal highlighted a negative bias to night-time (periods where solar radiation $(R g)$ was $<20 \mathrm{~W} \mathrm{~m}^{-2}$ ) values, with $28 \%$ of all nighttime $\mathrm{CO}_{2}$ fluxes less than zero. This suggests net assimilation of $\mathrm{CO}_{2}$ by the forest vegetation at night, very unlikely in this ecosystem and therefore indicative of advection events, which are likely at this site under stable night-time conditions. Although there is no commonly agreed method to account for advection (Aubinet and Feigenwinter, 2010) our approach is consistent with the general logic of other methods. Other authors have recorded such errors with open-path setups (Lloyd, 2006; Hirata et al., 2007) and it is unlikely that such erroneous fluxes were caused solely by instrument error or interference by precipitation, with only $25 \%$ of erroneous results removed by implementing LE and $\mathrm{H}$ thresholds for Wytham Woods data. Van Gorsel et al. (2009) review the technical considerations for assessment of night-time flux data, including the use of change in storage of $\mathrm{CO}_{2}$. Lacking such storage data for Wytham, negative night-time $\mathrm{CO}_{2}$ fluxes were removed and replaced by values generated using the gap-filling algorithm (see below) and the subsequent results were compared to calculations where these negative values were retained.

\section{Instrument surface heat exchange}

Where open path infrared gas analysers are used, differences between instrument surface temperature and ambient air temperature can lead to localised sensible heat fluxes that affect $\mathrm{CO}_{2}$ densities measured in the instrument path (Burba et al., 2008). Since the meteorological data for Wytham lacked appropriate solar radiation data, it was not possible to estimate the potential influence of instrument surface heat exchange upon $\mathrm{CO}_{2}$ fluxes. Fortunately radiation measurements recorded by new flux equipment installed in April 2009 on the Wytham flux tower were suitable for the application of the aforementioned "Burba" correction. The application of this correction within primary data processing for post April 2009 flux data revealed a maximum overestimation of $\mathrm{CO}_{2}$ uptake of $5 \%$, though only in May 2010, where cool temperatures and high solar radiation coincided. For other months the correction is negligible $(\sim 0.5 \%)$ and the errors in the correction become as large as the correction itself. We assume that the "Burba" correction would have similar (negligible) impacts on the earlier 2007-2009 flux data. The "Burba" correction has the largest impact in relatively cold climates, especially where total fluxes are small and thus errors under certain meteorological conditions can have a relatively large impact upon net fluxes. Wytham's climate is generally mild. The correction mainly eradicated some of the negative night-time values - something which we already attempted to account for. 


\subsubsection{Gap filling}

The next processing step was to replace the deleted data with appropriate gap-filled values, an essential requirement for the calculation of complete carbon budgets. Several techniques have been developed to estimate flux values for missing data, based upon either interpolation from neighbouring values or more complex estimates such as derivations from non-linear regression models. However, biases associated with different gap-filling techniques are generally small (Papale et al., 2006; Moffat et al., 2007). In our study, missing data, spike removal and the application of LE and $\mathrm{H}$ thresholds resulted in the removal of $21 \%$ of $\mathrm{CO}_{2}$ flux values (rising to $32.5 \%$ with the deletion of negative night-time values) from the final output file. To recreate a continuous flux dataset for the purposes of calculating carbon balances, deleted values were substituted with estimates using the standard gap-filling procedure employed by CarboEurope (http://www.bgc-jena.mpg.de/bgc-mdi/html/eddyproc/ index.html: Reichstein et al., 2005). This Marginal Distribution Sampling (MDS) technique is effectively an enhancement of look-up tables whereby flux measurements are correlated to meteorological conditions and produced consistently accurate results when compared to other, more complex, techniques (Moffat et al., 2007). MDS accounts for temporal auto-correlation of fluxes, replacing missing data with the average value under similar meteorological conditions within a 7-day window. Where data gaps are large, the averaging window can be increased from the 7 days, but these data are assigned to a lower accuracy category. MDS requires flux data, in the form of $\mathrm{CO}_{2}, \mathrm{H}$ and $\mathrm{LE}$ fluxes and the meteorological variables: solar radiation, relative humidity, air temperature, soil temperature and vapour pressure deficit.

\subsubsection{Friction velocity correction}

Underestimation of eddy covariance fluxes can occur during calm night-time periods of low turbulence and stable atmospheric stratification if surface air containing respired $\mathrm{CO}_{2}$ drains laterally from the study area, thus passing undetected by the IRGA. Data from these periods were corrected by implementing a standard friction velocity $\left(\mathrm{u}_{*}\right)$ correction (Goulden et al., 1996) to calculate night-time fluxes during well-mixed periods of moderate turbulence, which subsequently replaced data from calm periods where thermal stratification and drainage may have occurred. The method described by Reichstein et al. (2005) was used, with the gapfilled dataset split into six temperature categories of equal sample size and further subdivided into 20 classes of $u_{*}$ values. The $u_{*}$ threshold for each temperature class was calculated as the $u_{*}$ class where the night-time flux reached $\geq$ $95 \%$ of the average flux within the higher $u_{*}$ classes. The final threshold was calculated as the median of the temperature classes and applied in 3 month subsets to account for seasonal variation. A default value of $0.4 \mathrm{~m} \mathrm{~s}^{-1}$ was used if no threshold could be calculated. This value corresponded well with manual estimates. Incorrect application of the $u_{*}$ correction may occur if $\mathrm{CO}_{2}$ respired on calm nights is not lost through advection but instead stored under the canopy and released as a pulse of $\mathrm{CO}_{2}$ following daybreak (Moncrieff et al., 1996). Due to the open nature of the canopy at Wytham Woods and the uneven topography it was assumed that such "canopy storage" would not occur on a frequent basis, and there is very little evidence of morning "spikes" as stored $\mathrm{CO}_{2}$ is flushed from the canopy.

\subsubsection{Partitioning}

Flux data were partitioned into gross primary productivity (GPP) and respiration using the online CarboEurope partitioning tool (Reichstein et al., 2005) available at http://www. bgc-jena.mpg.de/bgc-mdi/html/eddyproc/index.html. For night-time values (where solar radiation $<20 \mathrm{~W} \mathrm{~m}^{-2}$ ), the Lloyd-Taylor regression model (Lloyd and Taylor, 1994) was used to estimate respiration rates from air temperature (in fact, the largest source of ecosystem respiration at this site is stem respiration (Fenn et al., 2011) and our implicit assumption is that stem near-surface temperature, which was not monitored, closely tracks air temperature). The estimated value of respiration was then assigned to the central time point of the averaging interval ( 30 or $60 \mathrm{~min}$ ) and linearly interpolated between time periods. GPP was subsequently calculated as the difference between NEE and respiration. As both negative GPP values, and non-zero GPP values at night, are impossible in the majority of plants, such values were interpreted as errors and forced to zero. Net ecosystem productivity (NEP) was calculated by subtracting respiration from this corrected GPP (in contrast to the measured NEE). Partitioning was undertaken using air temperature both at 30 minute intervals and an artificial diurnal cycle of half the amplitude of observed data to simulate the impacts of potential temperature buffering within the woods compared to the grassland weather station. The differences between final annual totals for GPP and ecosystem respiration using both temperature datasets were negligible $(<3.5 \%)$.

\section{$2.4 \mathrm{CO}_{2}$ fluxes and weather data}

Meteorological variables were associated with $\mathrm{CO}_{2} \mathrm{NEE}$ values for both hourly and half-hourly time averaging intervals by matching time and date for each period. As only hourly meteorological data were available, $30 \mathrm{~min}$ averages were estimated for (a) 0-30 min and (b) 30-60 min in each hour using the following equations:

$$
\begin{aligned}
& V(a)=\frac{(3 V(x)+V(x-1))}{4} \\
& V(b)=\frac{(3 V(x)+V(x+1))}{4}
\end{aligned}
$$


Here, $V=$ the desired half-hourly meteorological variable value, $x=$ the hour in which $V$ resides. This weighting was applied because the mid-point of each half hour interval (e.g. 12:15) is $3 / 4$ of the way between the mid-point of the adjacent hour (e.g. 11:30) and the mid-point of the current hour (e.g. 12:30). Hence such a weighted estimate is a better estimate of the half-hourly value. Precipitation, recorded as a total over each hourly period, was halved to produce totals for each half-hourly period. The meteorological variables were then correlated with pre gap-filled $\mathrm{CO}_{2}$ fluxes for the relevant time period to produce $R^{2}$ (co-efficient of determination) values. Curves were fitted to monthly plots of daytime (where solar radiation $\geq 20 \mathrm{~W} \mathrm{~m}^{-2}$ ) $\mathrm{CO}_{2}$ flux versus solar radiation (as the main meteorological variable driving $\mathrm{CO}_{2}$ fluxes), using a mixture of first to third degree polynomial equations that best described the relationship between these two variables for each month. Residuals calculated as the difference between observed daytime $\mathrm{CO}_{2}$ fluxes and those predicted using polynomial equations for each month were then compared to other meteorological variables. Where appropriate, linear regression was used to test the significance of the aforementioned relationships. Daytime and night-time data were analysed at both half hourly and daily average intervals, for individual months and spring (March, April, May), summer (June, July, August), autumn (September, October, November) and winter (December, January, February).

\section{Results and analysis}

\subsection{Meteorological data}

Daily averages of key meteorological variables are shown in Fig. 3. Average annual precipitation over the study period was $902.4 \mathrm{~mm}$ - over $170 \mathrm{~mm}$ (or $24 \%$ ) greater than the average for Wytham between 1992 and 2009. Temperatures were slightly below average, with a mean annual air temperature of $9.7^{\circ} \mathrm{C}$. Winds were predominantly south westerly, coming from this direction for approximately $55 \%$ of the study period. Average daily air temperature in July was $16.0^{\circ} \mathrm{C}$ with a maximum hourly value of $26.7^{\circ} \mathrm{C}$ in 2008 . December, January and February were the coldest months, with average daily air temperatures of $4.3^{\circ} \mathrm{C}$, with minimum hourly air temperatures occasionally reaching $-5.0^{\circ} \mathrm{C}$. A surface energy budget ratio of 0.74 was calculated for $24 \mathrm{~h}$ periods over the study period. A review of studies using eddy covariance over forests suggests that a value of 0.7 to 0.8 is typical (Baldocchi, 2008). It is not yet fully understood why some energy fluxes are missing at forest eddy covariance studies in general, although undetected low-frequency transport and advection is one likely possibility (Malhi et al., 2004).
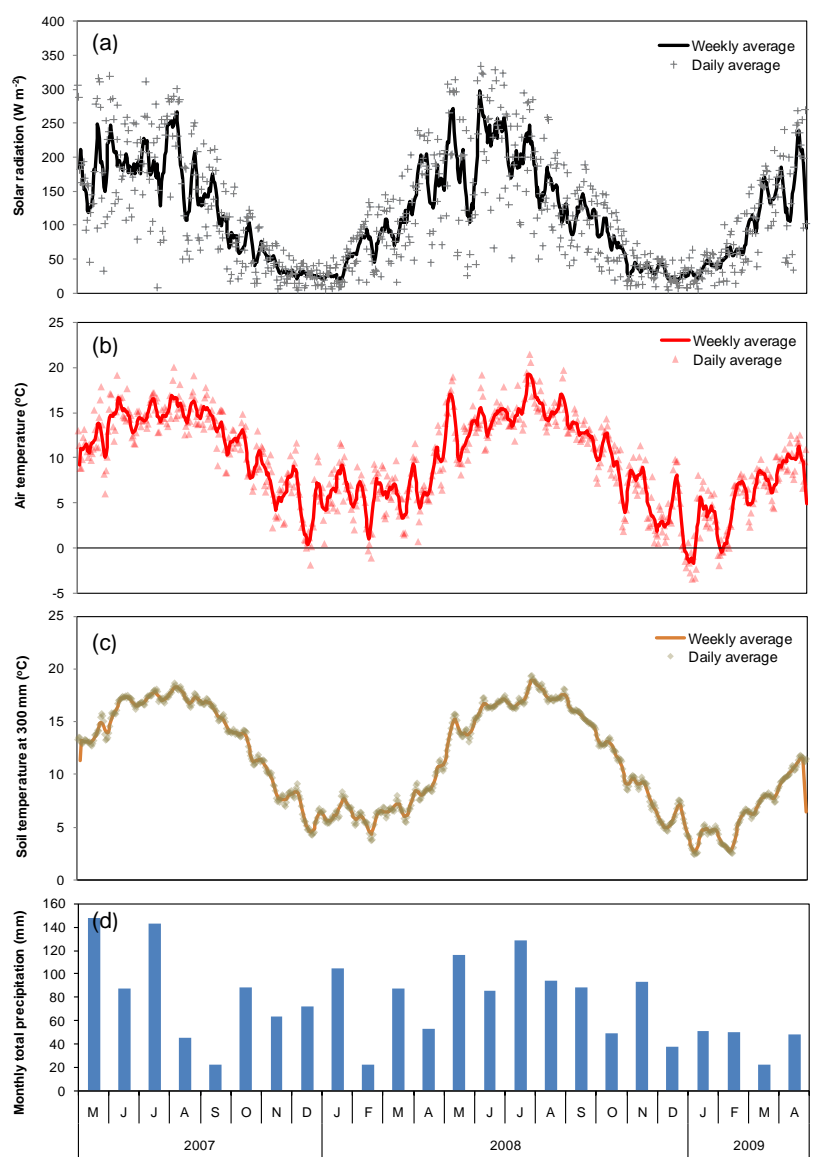

Fig. 3. Variation of (a) solar radiation; (b) air temperature; (c) soil temperature at $300 \mathrm{~mm}$ depth; (d) monthly total precipitation over the study period.

\subsection{Carbon dioxide flux sensitivity to processing procedures}

Figure 4 shows the cumulative impact of secondary processing approaches upon $30 \mathrm{~min}$ interval NEE values for 2008. The daytime fluxes are predominantly negative, representing net assimilation of carbon into the forest ecosystem. The positive night-time (where solar radiation $(R g)<20 \mathrm{~W} \mathrm{~m}^{-2}$ ) fluxes show net respiration. With the exception of the original and spike-removed fluxes, the daytime fluxes show remarkable similarity between processing approaches, peaking at around $-12 \mu$ mols $\mathrm{CO}_{2} \mathrm{~m}^{-2} \mathrm{~s}^{-1}$ in June. However, the use of different techniques and corrections when processing raw flux data can have a large impact upon NEE (Guan et al., 2006; Zhang et al., 2006). In our study, there is a marked difference between the night-time average hourly fluxes for secondary stage processing approaches. Although the resultant fluxes are higher than typical winter values for deciduous forest of $\sim 1 \mu \mathrm{mol} \mathrm{CO} \mathrm{m}^{-2} \mathrm{~s}^{-1}$ (Baldocchi and Valentini, 2004), the negative night-time $\mathrm{CO}_{2}$ flux removal correction appears to most realistically represent winter night-time 


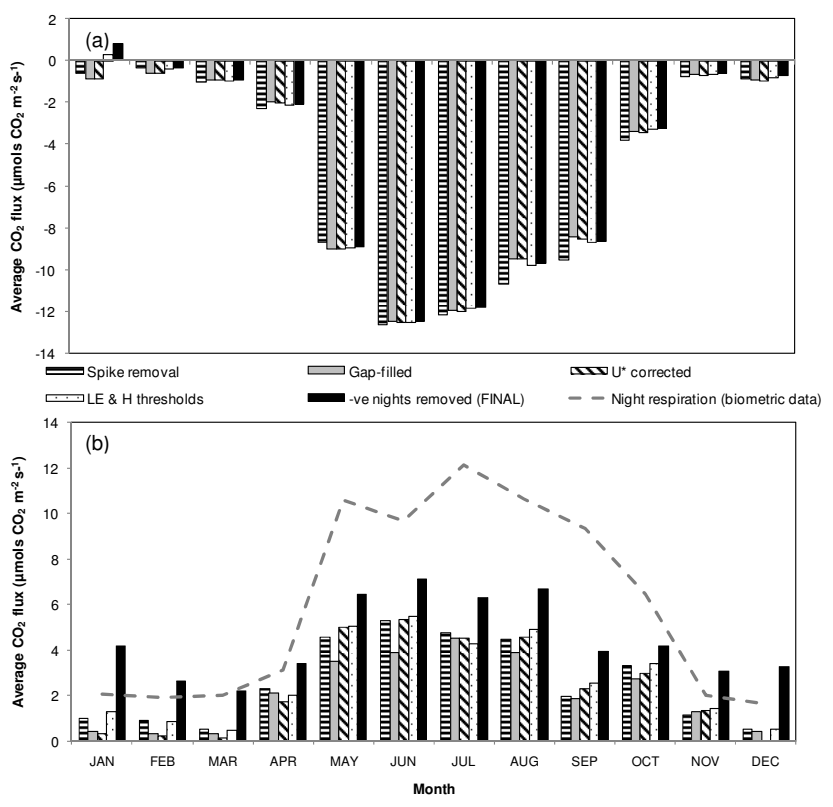

Fig. 4. (a) Day and (b) night-time flux sensitivity attributed with secondary stage processing approaches. Each stage represents cumulative processing approaches with increasing constraints upon the flux data, removing "erroneous" results and replacing with gapfilled data. Estimation of respiration from chamber data (soils, stems and leaves) overlay night-time fluxes.

fluxes when compared to chamber measurements of combined autotrophic (predominantly stem and leaf) and heterotrophic (predominantly soil and litter) respiration (Fenn et al., 2011) in Fig. 4. Therefore, this correction was applied to calculate total carbon uptake. Although chamber measurements represent daytime $\mathrm{CO}_{2}$ efflux, differences between day and night-time respiration are assumed to be small.

\subsection{Carbon fluxes at Wytham Woods}

\subsubsection{NEE fluxes}

For the period 1 May 2007 to 30 April 2009 approximately $43 \%$ of the total half-hourly flux values were removed or missing (following $u_{*}$ corrections) and thus required gapfilling. The largest periods of absent data were fortnights in May 2007 and July 2008 and the last week of April 2009. $91 \%$ of the gaps filled were classified as category A, the highest degree of estimation accuracy, whilst $8.5 \%$ and $0.5 \%$ were calculated as categories $\mathrm{B}$ and $\mathrm{C}$ respectively. Evaluation statistics for artificial gaps created by the gap-filling process show strong correlations when compared to measured data, providing confidence in the representativeness of the gap-filled fluxes.

The diurnal and seasonal "pulse" of carbon fluxes in Wytham Woods for the study period is depicted in Fig. 5, which shows changes in gap-filled NEE (in $\mu$ mols $\mathrm{CO}_{2} \mathrm{~m}^{-2} \mathrm{~s}^{-1}$ ) with time of day and year. The dark blue areas represent maximum $\mathrm{CO}_{2}$ sequestration - occurring during the spring and summer months between daylight hours. Indeed, the impact of day length is illustrated by the changing width of the NEE "pulses". Their ovoid shape also suggests rapid rise in NEE during the spring, followed by slower decline in the autumn. Net sequestration typically starts around 1 hour after daybreak and net respiration $1 \mathrm{~h}$ prior to nightfall. The lowest $\mathrm{CO}_{2}$ fluxes were observed in January, where net sequestration of carbon was rare even during maximum PAR. It is surprising that any net photosynthesis was detected during this period as the only photosynthetically active plants are evergreen trees and shrubs, some herbaceous species and bryophytes (mosses and a small number of liverworts). Evergreen trees and shrubs cover a very small proportion of the total woodland area. By March net sequestration occurred during daylight hours of 08.00 to $17.00 \mathrm{GMT}$. Half-hourly $\mathrm{CO}_{2}$ assimilation rates peaked in June at around $20 \mu$ mols $\mathrm{CO}_{2} \mathrm{~m}^{-2} \mathrm{~s}^{-1}$ between 11.00 and 14.00 GMT. The symmetrical shape of diurnal NEE suggests little evidence of factors limiting photosynthesis such as afternoon water stress (the summers of 2007 and 2008 were atypically wet) or "pulses" of respiration following daybreak - indicating little canopy storage of $\mathrm{CO}_{2}$ respired at night.

Graphs of latent heat of evaporation (LE) and sensible heat $(\mathrm{H})$ fluxes over the study period are shown in Appendix A (Fig. A2). A slight net negative flux was found for $\mathrm{H}$, with an average of $-14.3 \mathrm{~W} \mathrm{~m}^{-2}$ over the study period. It is thought that any bias caused by instrument malfunction or interference was removed by introducing thresholds (see Sect. 2.3.2). Remaining bias may result from the topography of the site and the hillside position of the flux tower, resulting in cool air sinking away from the study site, daytime advection of warmer air from surrounding fields, and other advection-based complications. Other studies have also noted such a negative $\mathrm{H}$ bias (Clement, 2004). The average LE over the study period was $53.8 \mathrm{~W} \mathrm{~m}^{-2}$, equal to an annual evapotranspiration rate of $690 \mathrm{~mm}$. This represents $76 \%$ of precipitation over study period, but $95 \%$ of average long term precipitation, suggesting that Wytham Woods is likely to be water limited in late summer during average condition years.

\subsubsection{Partitioned fluxes}

Figure 6 shows the daily $30 \mathrm{~min}$ average $\mathrm{CO}_{2}$ flux estimates for gross primary productivity (GPP), respiration and net ecosystem productivity (NEP) from May 2007 to April 2009. The bold lines represent weekly averages for the partitioned values (GPP and $R_{\mathrm{e}}$ ). Positive GPP and NEP values represent net sequestration by the forest ecosystem; negative values indicate a net loss of $\mathrm{CO}_{2}$ to the atmosphere. Respiration values represent net exchange of $\mathrm{CO}_{2}$ from the ecosystem to the atmosphere. Half-hourly averaged GPP peaks at around $17 \mu$ mols $\mathrm{CO}_{2} \mathrm{~m}^{-2} \mathrm{~s}^{-1}$ between mid-June to early July and 


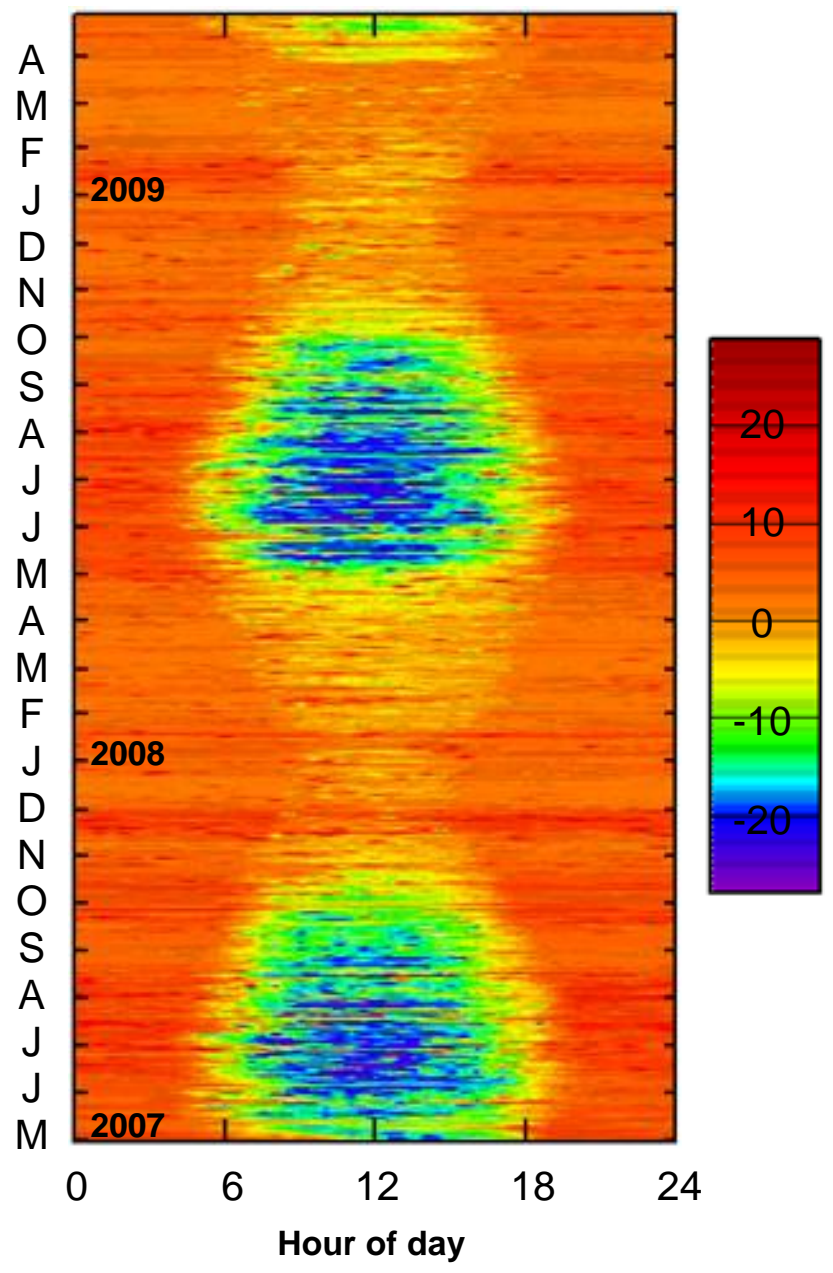

Fig. 5. The net ecosystem exchange (NEE) "fingerprint" of Wytham Woods showing diurnal (x-axis) and seasonal (y-axis) $\mathrm{CO}_{2}$ fluxes in $\mu$ mols $\mathrm{CO}_{2} \mathrm{~m}^{-2} \mathrm{~s}^{-1}$, generated using CarboEurope's online partitioning tool.

decreases to a minimum of around $1-1.5 \mu$ mols $\mathrm{CO}_{2} \mathrm{~m}^{-2} \mathrm{~s}^{-1}$ in the winter months. Respiration fluctuates to a lesser extent than GPP on an annual scale, but more on a week-byweek basis. Increases in soil temperature in the summer months correlate well with increasing rates of respiration, as expected (Reichstein et al., 2005), with peaks in respiration corresponding with peaks in soil temperature. Respiration decreases to $\sim 4 \mu$ mols $\mathrm{CO}_{2} \mathrm{~m}^{-2} \mathrm{~s}^{-1}$ in late August/early September 2007, possibly a result of unseasonal dry conditions in August and September $(63 \%$ and $28 \%$ of the 1992 to 2008 average August and September rainfall totals respectively). Respiration peaks occurring in late October/early November in both 2007 and 2008 do not appear to be driven by corresponding rises in soil temperature (Fig. 3). These peaks probably result from the decomposition of fresh leaf litter following peak litterfall and thus a rapid decline in leaf area index between mid October and mid November (Fenn,

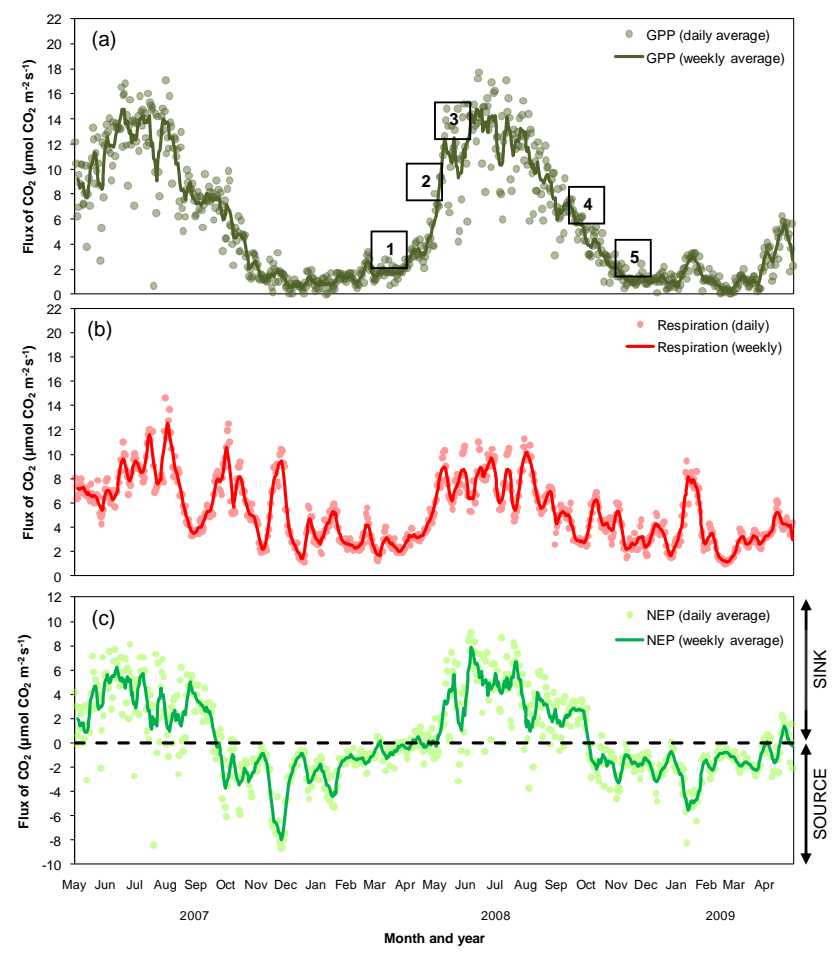

Fig. 6. Partitioned flux from Wytham Woods showing (a) gross primary productivity (GPP), (b) ecosystem respiration $\left(R_{\mathrm{e}}\right)$ and (c) net ecosystem productivity (NEP) over the study period. Dots indicate daily mean values, lines trace weekly mean values. Stages of GPP rise have been overlaid; stage (1) suggests the period of ground flora activity, stage (2) the period of rapid canopy leaf-out, and stage (3) the slow rise to mid-summer peak. Stages of GPP decline represent (4) peak litterfall in early to mid October and (5) minimum leaf area index.

2010). Respiration peaks in late December 2008 and January 2009 seem too late for leaf litter decay, and are possibly caused by periods of increased soil temperature and wind speeds between cold (sub-zero temperature) periods.

The ecosystem was a net source of $\mathrm{CO}_{2}$ (negative NEP) from the start of January to mid-April and from mid-October to the end of December, averaging around $-2 \mu$ mols $\mathrm{CO}_{2} \mathrm{~m}^{-2} \mathrm{~s}^{-1}$. In early April NEP becomes positive (net carbon uptake) as rates of photosynthesis become greater than respiration rates. The onset of net carbon uptake around 20 April (in 2008) coincides with the time of year when daily average soil temperature equals the mean annual air temperature of $9.7^{\circ} \mathrm{C}$, reinforcing similar findings in other temperate forests (Baldocchi et al., 2005). The increases in GPP or NEP appear to occur in three distinct stages (Fig. 6). In stage 1 GPP rises slowly until the start of May, likely a result of expansion of ground flora and early leafing trees. This is followed by a rapid rise during May (stage 2) as much of the forest canopy has come into leaf and started photosynthesising. The final rise to a mid-summer 
peak (3) could result from late developing trees such as oak reaching full photosynthetic capacity by mid-June, which has been measured at Wytham (Morecroft et al., 2003), as well as a result of increasing sun elevation and day length. GPP reaches a maximum of $17.7 \mu$ mols $\mathrm{CO}_{2} \mathrm{~m}^{-2} \mathrm{~s}^{-1}$ in mid-June, corresponding to a peak NEP of $8.8 \mu$ mols $\mathrm{CO}_{2} \mathrm{~m}^{-2} \mathrm{~s}^{-1}$. The rapid decline in GPP at the start of October corresponds with senescence (leaf aging) and abscission (leaf-fall). Day-today fluctuations in GPP or NEP following leaf emergence during the spring and summer months are likely to reflect changes in weather conditions. One definition of the forest growing season (ignoring ground flora activity) would be from the start of the rapid rise in GPP (canopy leafout) around 1 April to the flattening of the GPP curve by 1 November. This period is 214 days. The net carbon uptake period (the period between the first and last days with positive NEP) is much shorter, at 151 days.

Approximately $55 \%$ of the measured total carbon uptake recorded between May 2007 and April 2009 originated from areas to the southwest of the flux tower, with an average (pre-gap filled) half hourly NEE of $-2.4 \mu$ mols $\mathrm{CO}_{2} \mathrm{~m}^{-2} \mathrm{~s}^{-1}$ (Appendix A, Fig. A3). This is very close to the equivalent average value of $-2.3 \mu$ mols $\mathrm{CO}_{2} \mathrm{~m}^{-2} \mathrm{~s}^{-1}$ over all wind directions. It therefore seems unnecessary to remove flux data originating from outside the southwest to compare carbon uptake to biometric estimates from plots to the southwest of the tower, since this removal would result in approximately $70 \%$ of flux data requiring "gap filling" - decreasing the level of confidence that could be applied to the results. The greatest carbon sequestration rates (NEE of $-4.5 \mu$ mols $\mathrm{CO}_{2} \mathrm{~m}^{-2} \mathrm{~s}^{-1}$ ) occurred in areas to the north/northwest of the flux tower (undisturbed ancient forest and 20th century plantations). The large seasonal variation in $\mathrm{CO}_{2}$ sequestration rates detected from different wind directions may reflect the mixed composition of tree and undercanopy species in Wytham Woods and thus changes in seasonal photosynthetic activity between species.

\subsubsection{Total carbon uptake}

Over the period 1 May 2007 to 30 April 2009 we estimate cumulative NEP to be $1.2 \mathrm{Mg} \mathrm{Cha}^{-1} \mathrm{yr}^{-1}$. GPP is estimated at $21.1 \mathrm{MgCha}^{-1} \mathrm{yr}^{-1}$ and $R_{\mathrm{e}} 19.8 \mathrm{MgCha}^{-1} \mathrm{yr}^{-1}$. GPP, $R_{\mathrm{e}}$ and NEP were all highest in the summer, with net respiration occurring in the autumn and winter. Figure 7 plots the partitioned fluxes for each month of the study period. GPP shows very little variation in its seasonal cycle, with 2008 showing slightly higher spring uptake and slightly greater autumn decline than 2007 . Higher spring temperatures $\left(+1.5^{\circ} \mathrm{C}\right.$ in 2008) may have encouraged earlier leaf-out of the deciduous canopy (Morecroft et al., 2003). Ecosystem respiration showed greater variability, particularly in the autumn and winter months (September-January), but also in midsummer (July). In most of these periods 2007 ecosystem respiration rates were substantially higher than 2008 rates.
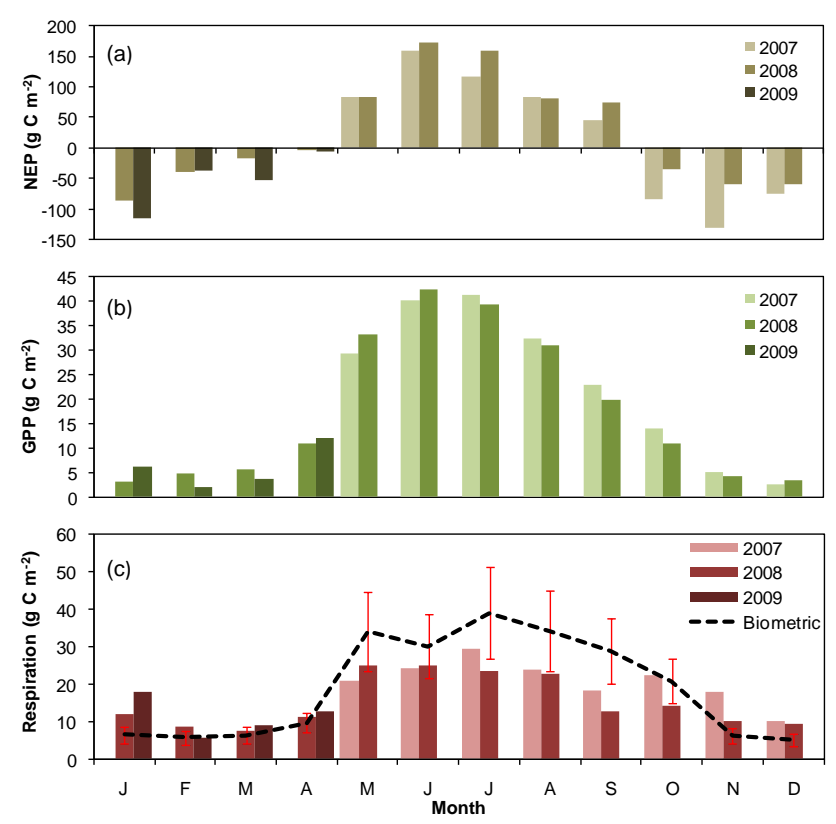

Fig. 7. Monthly total NEP (a) and partitioned monthly totals for (b) GPP and (c) respiration. For $R_{\mathrm{e}}$ monthly total biometric/chamber estimates of ecosystem respiration during 2008 (Fenn et al., 2011) with error bars have been overlaid for comparison.

Periods of higher respiration (between years) appear to correspond to periods of higher temperature, reinforced by our findings in Sect. 3.3.4. According to Fenn et al. (2010) variation in soil temperature between years at this Wytham site could explain up to $50 \%$ of variance in $\mathrm{CO}_{2}$ soil efflux, and soil moisture a further $18 \%$ of the residual variance. On this basis it is likely that greater losses of carbon to the atmosphere observed in October to December 2007 compared to 2008 are the result of higher rates of root and microbial respiration due to higher air temperatures $\left(+1^{\circ} \mathrm{C}\right)$, and increased soil moisture in the litter and soil layers suggested by heavier rainfall for these months in 2007. As soil and litter respiration account for only a small component of ecosystem respiration at the site (17\% and $8 \%$ respectively; Fenn et al., submitted), the differences in ecosystem respiration between years also suggest changes in stem and leaf respiration rates between years, probably also linked to temperature variation.

As a consequence of lower ecosystem respiration rates in 2008, greater net sequestration occurred in 2008 compared to 2007, with smaller net losses of carbon to the atmosphere in the late autumn and early winter months (Fig. 7). Hence variation in ecosystem respiration appears to be the stronger driver of variation of net carbon uptake, at least over the twoyear study period, reinforcing findings that ecosystem respiration rates drive variation in net ecosystem carbon exchange in European forests (Valentini et al., 2000). Longer term studies have shown convincing interannual variability in the balance between GPP and $R_{\mathrm{e}}$ (Ciais et al., 2005; Urbanski et al., 2007; Delpierre et al., 2009). 
In 2008, we found Wytham Woods to be a substantial sink of carbon of NEP $265 \mathrm{~g} \mathrm{C} \mathrm{m}^{-2}$ or approximately $2.7 \mathrm{Mg} \mathrm{Cha}^{-1}$ over the course of the calendar year. We explored the sensitivity of this result to averaging period by comparing $30 \mathrm{~min}$ averaging intervals to carbon sequestration estimated using hourly intervals. Using $60 \mathrm{~min}$ intervals generates a total annual estimate of carbon uptake of $3.6 \mathrm{Mg} \mathrm{Cha}^{-1}$ for $2008,33 \%$ greater than using $30 \mathrm{~min}$ intervals. This difference can be accounted for by the mean $30 \mathrm{~min}$ and $60 \mathrm{~min}$ NEE (prior to adjustments made to calculate NEP), which are -0.53 and $-0.74 \mu$ mols $\mathrm{CO}_{2} \mathrm{~m}^{-2} \mathrm{~s}^{-1}$ respectively. This may result from the detection of lower frequency turbulence when longer averaging intervals are used (Malhi et al., 2004) although increasing averaging periods can enhance advection problems. Some authors present annual carbon fluxes in cumulative NEE, which were $\sim 75 \%$ of NEP estimates for our 2008 results. However, using NEP (calculated as corrected GPP minus respiration) may give a more accurate estimate of net carbon sequestration by providing further correction for erroneous night-time values. It is worth highlighting the impacts of removing negative nighttime $\mathrm{CO}_{2}$ fluxes, in addition to the spurious peaks removed by process outlined in Sect. 2.3.1. Including these values or removing them alongside an equivalent $\mathrm{NEE}$ of positive data produced an estimated carbon sink of $8.2 \mathrm{Mg} \mathrm{C} \mathrm{ha}^{-1}$ for 2008, a value which seems extremely implausible when compared to other biometric data (see Sect. 4). Although somewhat problematic and potentially leading to a bias in cumulative NEE, it seems that removal of negative night-time fluxes (prior to gap filling) is the most appropriate data analysis approach for this study that maintains consistency with the plausible carbon cycle of Wytham Woods.

\subsubsection{Meteorological drivers and canopy physiological parameters}

Correlating $\mathrm{CO}_{2}$ fluxes with individual meteorological variables is difficult due to strong temporal auto-correlations associated with the seasonal cycle that hinder identification of specific causal factors. Solar radiation was found to be the primary driver of photosynthesis with $R^{2}=0.35$ for the positive non-linear relationship between all half hourly daytime solar radiation and NEE data. Analysis of daytime data from summer months when the tree canopy was in full leaf produced the highest $R^{2}$ values between these two variables $\left(R^{2}=0.53\right)$. Despite a linear response of $\mathrm{CO}_{2}$ fluxes to low levels of solar radiation $\left(<100 \mathrm{~W} \mathrm{~m}^{-2}\right)$, the overall curved fit and levelling-off of $\mathrm{CO}_{2}$ uptake rates above $700-800 \mathrm{~W} \mathrm{~m}^{-2}$ indicates when carboxylation becomes limiting. The $\mathrm{CO}_{2}$ compensation point (when canopy uptake equals ecosystem respiration) occurs at $\sim 60 \mathrm{~W} \mathrm{~m}^{-2}$. The zero solar radiation intercept is at an NEE of $2.3 \mu$ mols $\mathrm{CO}_{2} \mathrm{~m}^{-2} \mathrm{~s}^{-1}$ representing net release of $\mathrm{CO}_{2}$ to the atmosphere similar to the mean night-time respiration of $2.4 \pm 0.06 \mu$ mols $\mathrm{CO}_{2} \mathrm{~m}^{-2} \mathrm{~s}^{-1}$. Night-time fluxes showed

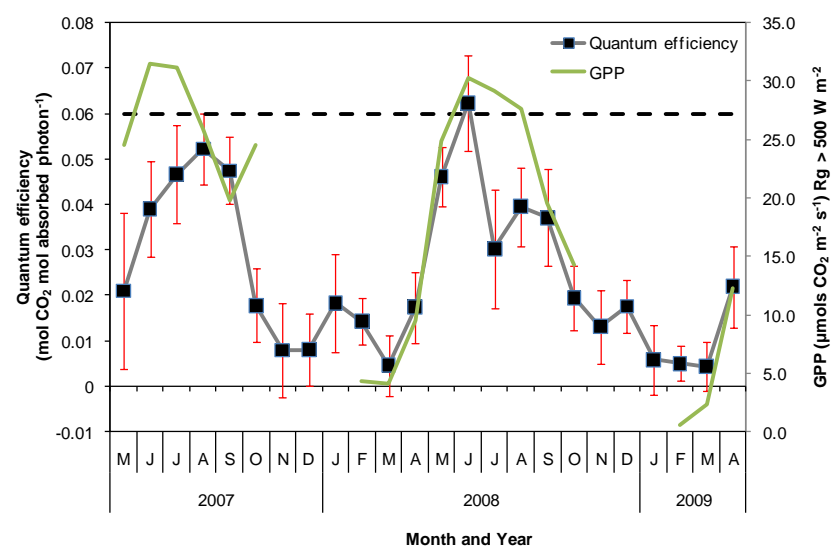

Fig. 8. Variation of quantum efficiency and GPP under high light (solar radiation $>500 \mathrm{~W} \mathrm{~m}^{-2}$ ), calculated from monthly data (theoretical maximum quantum efficiency is also shown).

unexpectedly weak but significant increases in NEE (respiration) with increasing soil temperature over the study period $\left(R^{2}=0.11, P<0.001\right)$, with a slightly stronger relationship during the spring months $\left(R^{2}=0.17, P<0.001\right)$.

The theoretical maximum quantum yield for photosynthesis in $\mathrm{C}_{3}$ species is about 0.06 mols $\mathrm{CO}_{2}$ per mol of absorbed photons (Farquhar et al., 1980). The maximum observed yield can be estimated using the slope of the light-response curve at low solar radiation ( 5 to $100 \mathrm{~W} \mathrm{~m}^{-2}$ ), when photosynthesis is restricted by photon availability rather than other limiting factors that become more influential at higher insolation. Assuming that photosynthetic active radiation (PAR) in $\mu$ mols photons $\mathrm{m}^{-2} \mathrm{~s}^{-1}=2.16 \times$ solar radiation in $\mathrm{W} \mathrm{m}^{-2}$ (Weiss and Norman, 1985) and that absorbed PAR $=0.9 \times$ incident PAR (as the average solar albedo of temperate deciduous forests is $\sim 12 \%$ ) linear regression through all data at low solar radiation gives an apparent yield of $0.024 \pm 0.002$ (95\% confidence) mols $\mathrm{CO}_{2}$ per mol of absorbed photons, or $40 \%$ of the theoretical maximum. Monthly variation in quantum efficiency is shown in Table 3 and Fig. 8, along with monthly averaged GPP and NEE values that represent maximum photosynthetic rate.

The quantum efficiency approaches theoretical maximum values in both years but with different timing, with a late summer peak in August 2007, and a sharp early summer peak in June 2008. The photosynthetic capacity (GPP under high light) shows a more consistent peak at about $30 \mu \mathrm{mol} \mathrm{CO} \mathrm{C}^{-2} \mathrm{~s}^{-1}$ over June-August in both years. This peak is relatively late after canopy leaf-out, and may reflect both the maturation of existing leaves and the late and secondary leafing of the oak canopy. This adds to canopy photosynthetic capacity while the sycamore and ash canopies have not begun to decline substantially in photosynthetic capacity. Furthermore, higher temperatures may also provide more favourable conditions for photosynthesis. Photosynthetic capacity declines strongly in September, 
Table 3. Monthly calculations for light use efficiency in Wytham Woods. Quantum efficiency is in units of mols $\mathrm{CO}_{2}$ per mol of absorbed photon. Blanks indicate too few data to generate quantum efficiency estimates via linear regression.

\begin{tabular}{|c|c|c|c|c|}
\hline \multicolumn{2}{|c|}{ Solar radiation $\left(\mathrm{W} \mathrm{m}^{-2}\right)$ : } & \multirow{2}{*}{$\begin{array}{c}5 \text { to } 100 \\
\begin{array}{l}\text { Quantum efficiency } \\
\text { ( } \pm \text { standard error) }\end{array}\end{array}$} & \multicolumn{2}{|c|}{$>500$} \\
\hline YEAR & MONTH & & $\begin{array}{c}\text { Average GPP } \\
\left(\mu \mathrm{mols} \mathrm{CO}_{2} \mathrm{~m}^{-2} \mathrm{~s}^{-1}\right)\end{array}$ & $\begin{array}{c}\text { Average NEE } \\
\left(\mu \mathrm{mols} \mathrm{CO}_{2} \mathrm{~m}^{-2} \mathrm{~s}^{-1}\right)\end{array}$ \\
\hline \multirow[t]{8}{*}{2007} & MAY & $0.021 \pm 0.017$ & $24.5 \pm 0.63$ & $-17.3 \pm 0.69$ \\
\hline & JUNE & $0.039 \pm 0.011$ & $31.5 \pm 0.59$ & $-21.8 \pm 0.58$ \\
\hline & JULY & $0.047 \pm 0.011$ & $31.1 \pm 0.39$ & $-20.5 \pm 0.39$ \\
\hline & AUGUST & $0.052 \pm 0.008$ & $25.9 \pm 0.51$ & $-15.5 \pm 0.43$ \\
\hline & SEPTEMBER & $0.047 \pm 0.007$ & $19.8 \pm 0.73$ & $-14.3 \pm 0.69$ \\
\hline & OCTOBER & $0.018 \pm 0.008$ & $24.5 \pm 1.55$ & $-10.3 \pm 1.47$ \\
\hline & NOVEMBER & $0.008 \pm 0.010$ & & \\
\hline & DECEMBER & $0.008 \pm 0.008$ & & \\
\hline \multirow[t]{12}{*}{2008} & JANUARY & $0.018 \pm 0.011$ & & \\
\hline & FEBRUARY & $0.014 \pm 0.005$ & $4.3 \pm 1.44$ & $-0.6 \pm 1.45$ \\
\hline & MARCH & $0.005 \pm 0.007$ & $4.1 \pm 0.34$ & $-1.2 \pm 0.44$ \\
\hline & APRIL & $0.017 \pm 0.008$ & $9.5 \pm 0.31$ & $-5.0 \pm 0.34$ \\
\hline & MAY & $0.046 \pm 0.006$ & $24.9 \pm 0.51$ & $-15.3 \pm 0.57$ \\
\hline & JUNE & $0.062 \pm 0.010$ & $30.2 \pm 0.34$ & $-21.1 \pm 0.32$ \\
\hline & JULY & $0.030 \pm 0.013$ & $29.1 \pm 0.51$ & $-20.2 \pm 0.50$ \\
\hline & AUGUST & $0.040 \pm 0.009$ & $27.7 \pm 0.52$ & $-19.7 \pm 0.61$ \\
\hline & SEPTEMBER & $0.037 \pm 0.011$ & $19.5 \pm 0.72$ & $-15.4 \pm 0.72$ \\
\hline & OCTOBER & $0.019 \pm 0.007$ & $14.3 \pm 0.58$ & $-7.8 \pm 0.72$ \\
\hline & NOVEMBER & $0.013 \pm 0.008$ & & \\
\hline & DECEMBER & $0.018 \pm 0.006$ & & \\
\hline \multirow[t]{4}{*}{2009} & JANUARY & $0.006 \pm 0.008$ & & \\
\hline & FEBRUARY & $0.005 \pm 0.004$ & $0.6 \pm 0.54$ & $1.3 \pm 0.57$ \\
\hline & MARCH & $0.004 \pm 0.005$ & $2.4 \pm 0.13$ & $1.3 \pm 0.17$ \\
\hline & APRIL & $0.022 \pm 0.009$ & $12.2 \pm 0.43$ & $-7.1 \pm 0.52$ \\
\hline \multicolumn{2}{|c|}{ ALL DATA } & $0.024 \pm 0.002$ & $22.9 \pm 0.25$ & $-15.0 \pm 0.21$ \\
\hline
\end{tabular}

preceding most litterfall (October/November), suggesting that leaf senescence strongly affects photosynthetic capacity well before leaf abscission. Quantum efficiency over the study site for the months of June to September was found to be greater than the values obtained from leaf observations on sunny days for oak and sycamore $(0.029 \pm 0.007$ and $0.021 \pm 0.006 \mathrm{mols} \mathrm{CO}_{2}$ per mol of absorbed photon respectively) made by Morecroft and Roberts (1999), where corresponding maximum irradiance saturated photosynthetic rates (per unit leaf area) were estimated at approximately 10.4 and $3.5 \mu \mathrm{mol} \mathrm{CO} \mathrm{CO}^{-2} \mathrm{~s}^{-1}$ respectively.

Other authors have found NEP in temperate deciduous forests to be sensitive to rainfall and vapour pressure deficit (VPD) during the summer months (Valentini et al., 2000; Knohl et al., 2003; Urbanski et al., 2007). The symmetrical rise and fall of diurnal changes in NEE in summer months suggests that water deficiency was not a limiting factor in the summers of 2007 and 2008 and comparison of 30 min residual daytime flux data against rainfall and vapour pressure deficit produced weak coefficient of determination values, typically $R^{2}<0.01$ even when analysed on a monthly or seasonal basis or warm days only where hourly air temperatures reached $>20^{\circ} \mathrm{C}$. Pulses of respiration following precipitation (Huxman et al., 2004) were not observed at Wytham, with declining NEP during sustained heavy rainfall caused by a lack of insolation resulting from heavy cloud cover. Comparison of $30 \mathrm{~min}$ residual daytime flux data against soil and air temperature also produced weak coefficient of determination values, where $R^{2}<0.01$.

\section{Discussion}

\subsection{Comparison with biometric data}

Our study area in Wytham Woods was estimated to be a carbon sink, sequestering approximately $1.24 \mathrm{MgCha}^{-1} \mathrm{yr}^{-1}$ between May 2007 and April 2009. Larger estimates of carbon sequestration were produced using hourly averaging intervals. This suggests the detection of low frequency 
turbulent fluxes, but these results may be more vulnerable to advection biases and detection of flux beyond the study site (Malhi et al., 2004). Validation of eddy covariance findings is provided by comparison with stock-based assessments of the carbon budget at Wytham. A double census of all 20358 trees within an 18 ha plot close to the flux tower (SP 457 089) shows an increase in carbon content stored in aboveground biomass of $1.5 \mathrm{MgC} \mathrm{ha}^{-1} \mathrm{yr}^{-1}$ between 2008 and 2010 (Butt, unpublished data). Including belowground biomass (approximately $20 \%$ of above-ground live biomass in temperate broadleaf woodlands; Jackson, 1996), increases the estimated uptake rate to $1.8 \pm 0.3 \mathrm{MgCha}^{-1} \mathrm{yr}^{-1}$. This inventory-based estimate is greater than, but comparable to, the eddy covariance estimate of $1.2 \mathrm{MgC} \mathrm{ha}^{-1} \mathrm{yr}^{-1}$ between 2007 and 2009. The inventory approach does not account for changes in soil carbon storage.

In addition to the net carbon flux comparison with woody biomass inventories, a second, largely independent, source of comparison is with ecosystem carbon fluxes estimated from scaling of NPP and autotrophic respiration measurements, recorded from a 1 ha plot within the footprint of the flux tower, deemed representative of the surrounding ecosystem (see Sect. 2.1 and 2.2). Our flux-based estimates of GPP and $R_{\mathrm{e}}$ (21.1 and $19.8 \mathrm{Mg} \mathrm{Cha}^{-1} \mathrm{yr}^{-1}$ respectively) can be compared with estimates of GPP and $R_{\mathrm{e}}(26.5 \pm 6.8$ and $24.8 \pm 6.8 \mathrm{MgC} \mathrm{ha}^{-1} \mathrm{yr}^{-1}$ respectively; Fenn et al., 2011). The flux tower values are about $20 \%$ lower than the biometric estimates, but within the uncertainty lower band of these estimates. It it is unclear whether the discrepancy lies in biometric overestimation (for example of stem $\mathrm{CO}_{2}$ efflux in the case of respiration) or flux underestimation.

The findings of these "top-down" and "bottom-up" studies can also be compared on a monthly basis as shown by respiration estimates in Fig. 7. Both approaches indicate similar magnitude and timing of seasonal variation, with respiration rates at their lowest in the winter months, then increasing rapidly into spring before peaking in July. Flux data respiration values tend to be lower in the summer months and greater during the winter months compared to the equivalent seasonal biometric findings. Overall, the biometric estimates of respiration seem to justify our approach to remove negative night-time fluxes. Although advection effects were not accounted for directly, negative night-time $\mathrm{CO}_{2}$ fluxes could be related to the advection of $\mathrm{CO}_{2}$ away from the flux tower resulting from the undulating topography at Wytham. Such advection effects can create negatively skewed flux distributions, and how to deal with such negative flux values is a major challenge for this study. Here we have shown that non-removal of negative night-time fluxes results in (i) values of night-time ecosystem respiration that appear to be too small compared to scaled-up chamber measurements; (ii) a large estimated net carbon uptake $\left(8.2 \mathrm{MgCha}^{-1}\right)$ that is clearly not consistent with the forest inventory observations. Hence the comparison with independent data provides two constraints that strongly suggest that removal and gap-filling
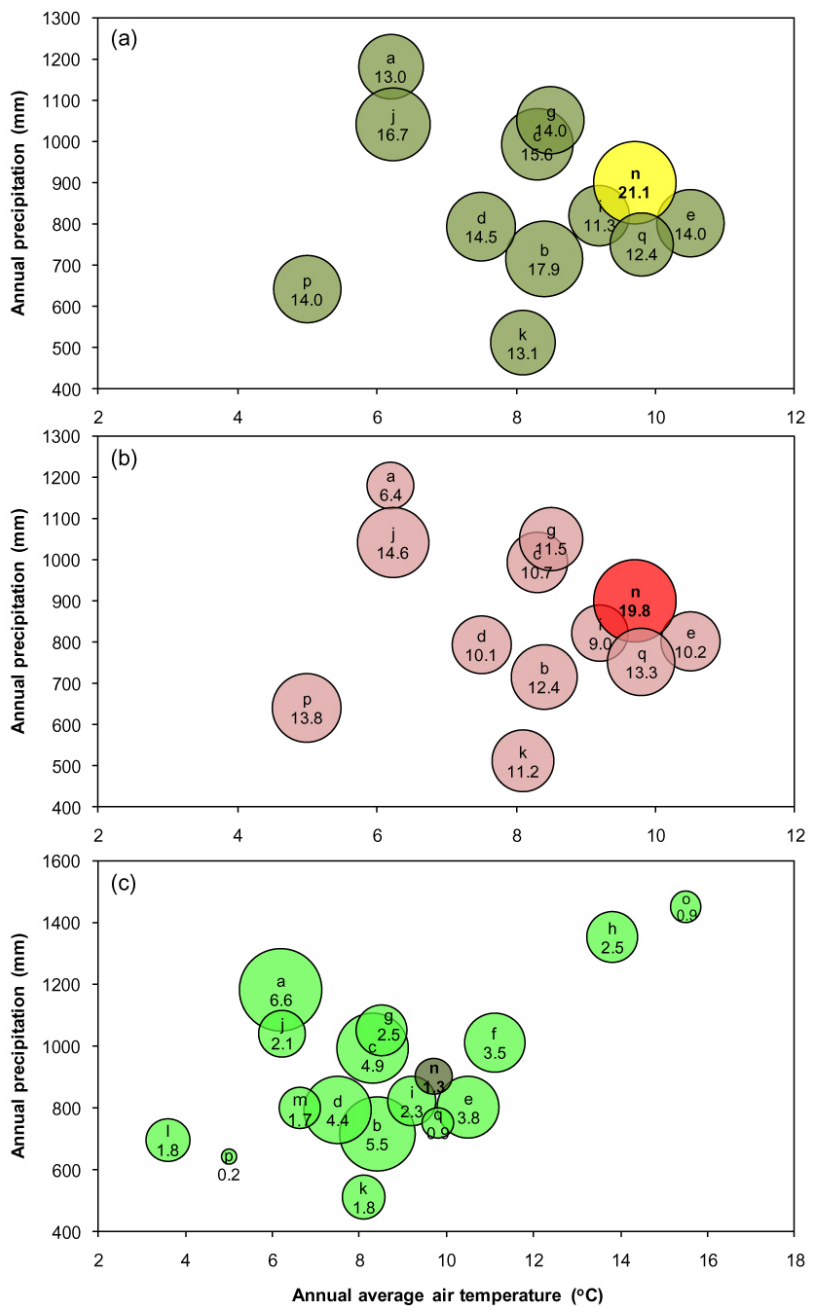

Fig. 9. Average annual (a) gross primary productivity (GPP), (b) ecosystem respiration $\left(R_{\mathrm{e}}\right)$ and (c) net ecosystem productivity (NEP) estimates from temperate deciduous forests across the globe in $\mathrm{MgC} \mathrm{ha}^{-1} \mathrm{yr}^{-1}$, plotted by site annual mean air temperature and precipitation. Site descriptions are given in Table 4, Wytham Woods is highlighted in each plot.

of negative night-time $\mathrm{CO}_{2}$ flux data is the most appropriate data analysis approach to correct for advection effects.

\subsection{Comparison with other woodlands}

Analysis of wind data and the estimated flux footprint suggests net sequestration within disturbed ancient deciduous woodland. To understand the context of such findings, it is necessary to compare our estimates to other eddy covariance based temperate deciduous woodland studies. Whilst it is important to note that timings of data collection and processing methods may vary between sites, Fig. 9 plots annual GPP, $R_{\mathrm{e}}$ and NEP according to annual mean temperature and total precipitation at sites across the globe to provide insights into the influence of climatic factors upon carbon 
Table 4. Collection of flux data from temperate deciduous or semi deciduous woodland across the globe. NEP, GPP and $R_{\mathrm{e}}$ in $\mathrm{Mg} \mathrm{Cha}^{-1} \mathrm{yr}^{-1}$. NEE used where NEP unavailable.

\begin{tabular}{|c|c|c|c|c|c|c|c|c|c|c|}
\hline Label & Country & Forest & Authors & NEP & GPP & $R_{\mathrm{e}}$ & $\begin{array}{r}\text { Mean } \\
\text { temp }\left({ }^{\circ} \mathrm{C}\right)\end{array}$ & $\begin{array}{r}\text { Annual } \\
\text { ppn (mm) }\end{array}$ & $\begin{array}{r}\text { Years of } \\
\text { data }\end{array}$ & Forest description \\
\hline A & Italy & Collelongo & (Valentini et al., 2000) & 6.6 & 13.0 & 6.4 & 6.2 & 1180 & 1 & Broadleaf deciduous woodland \\
\hline B & Germany & Kannenbruch & (Kutsch et al., 2005) & 5.5 & 17.9 & 12.4 & 8.4 & 714 & 1 & Oak subplot \\
\hline $\mathrm{C}$ & Germany & Hainich & (Knohl et al., 2003) & 4.9 & 15.6 & 10.7 & 8.3 & 992 & 2 & Beech dominated deciduous \\
\hline $\mathrm{D}$ & Belgium & - & (Valentini et al., 2000) & 4.4 & 14.5 & 10.1 & 7.5 & 792 & 1 & $\begin{array}{l}\text { Mixed + broadleaf deciduous } \\
\text { temperate }\end{array}$ \\
\hline E & UK & Alice Holt & $\begin{array}{l}\text { (Broadmeadow and } \\
\text { Matthews, 2003; Read } \\
\text { et al., 2009) }\end{array}$ & 3.8 & 14.0 & 10.2 & 10.5 & 800 & 1 & Broadleaf deciduous woodland \\
\hline $\mathrm{F}$ & USA & $\begin{array}{l}\text { Morgan Monroe } \\
\text { State Forest, } \\
\text { Indiana }\end{array}$ & (Curtis et al., 2002) & 3.5 & - & - & 11.1 & 1010 & 4 & $\begin{array}{l}\text { Eastern broadleaf forest } \\
\text { (continental) oak, maple, } \\
\text { blackgum, pine }\end{array}$ \\
\hline & Synthes & s of global data & (Luyssaert et al., 2007) & 3.1 & 13.8 & 10.5 & Varied & Varied & - & Temperate humid deciduous \\
\hline G & USA & $\begin{array}{l}\text { Harvard Forest, } \\
\text { New England }\end{array}$ & (Urbanski et al., 2007) & 2.5 & 14.0 & 11.5 & 8.5 & 1050 & 13 & $\begin{array}{l}\text { Mixed deciduous forest red oak, } \\
\text { red maple, red and white pine }\end{array}$ \\
\hline $\mathrm{H}$ & USA & $\begin{array}{l}\text { Walker Branch, } \\
\text { Tennessee }\end{array}$ & (Curtis et al., 2002) & 2.5 & - & - & 13.8 & 1350 & 6 & $\begin{array}{l}\text { Eastern broadleaf forest oceanic } \\
\text { oak, maple, blackgum, pine }\end{array}$ \\
\hline I & France & Hesse & (Granier et al., 2000) & 2.3 & 11.3 & 9.0 & 9.2 & 820 & 1 & $\begin{array}{l}\text { Broadleaf deciduous temperate, } \\
\text { mainly Beech }\end{array}$ \\
\hline $\mathrm{J}$ & Japan & $\begin{array}{l}\text { Tomakomai } \\
\text { National Forest }\end{array}$ & (Hirata et al., 2007) & 2.1 & 16.7 & 14.6 & 6.2 & 1040 & 3 & Temperate larch plantation \\
\hline $\mathrm{K}$ & Denmark & Zealand & (Pilegaard et al., 2001) & 1.8 & 13.1 & 11.2 & 8.1 & 510 & 2 & Beech \\
\hline $\mathrm{L}$ & China & $\begin{array}{l}\text { Changbai } \\
\text { Mountain }\end{array}$ & (Guan et al., 2006) & 1.8 & - & - & 3.6 & 695 & 1 & $\begin{array}{l}\text { Mixed temperate pine, maple, } \\
\text { liden, ash, oak }\end{array}$ \\
\hline M & Canada & Ontario & (Lee et al., 1999) & 1.7 & - & - & 6.6 & 798 & 3 & $\begin{array}{l}\text { Mixed temperate forest, aspen, } \\
\text { maple, cherry, ash, pine }\end{array}$ \\
\hline $\mathrm{N}$ & UK & Wytham Woods & This study & 1.3 & 21.1 & 19.8 & 9.7 & 900 & 2 & Broadleaf deciduous woodland \\
\hline $\mathrm{O}$ & Japan & Yamashiro & (Kominami et al., 2008) & 0.9 & - & - & 15.5 & 1450 & 1 & Warm temperate mixed forest \\
\hline $\mathrm{P}$ & China & Laoshan & (Saigusa et al., 2008) & 0.2 & 14.0 & 13.8 & 5.0 & 640 & 1 & Larch \\
\hline Q & Belgium & $\begin{array}{l}\text { Campine region, } \\
\text { De Inslag }\end{array}$ & (Carrara et al., 2004) & -0.9 & 12.4 & 13.3 & 9.8 & 750 & 5 & $\begin{array}{l}\text { Mixed temperate woodland, } \\
\text { pine and oak }\end{array}$ \\
\hline
\end{tabular}

budgets. Of particular interest is Alice Holt in Hampshire, one of the few other sites in the UK where eddy covariance has been used to estimate carbon budgets in mature deciduous woodland. Here, between 1999 and 2006, average NEP was $\sim 4.4 \mathrm{Mg} \mathrm{Cha}^{-1} \mathrm{yr}^{-1}$ (Read et al., 2009). Partitioned Alice Holt flux data from 2000 (validated by stock-based measurements) estimates GPP at $\sim 14 \mathrm{MgCha}^{-1}$ and $R_{\mathrm{e}}$ at 10.2 $\mathrm{Mg} \mathrm{Cha}^{-1}$ (Broadmeadow and Matthews, 2003). With similar species composition to Wytham Woods, it is possible that greater NEP at Alice Holt is a result of more intensive commercial management practices over the last few decades (Benham, 2008). The removal and regeneration of understory shrubs or introduction of saplings is likely to increase the rate of $\mathrm{CO}_{2}$ assimilation from the atmosphere (Ryan et al., 1997). Both GPP and $R_{\mathrm{e}}$ estimates at Wytham are substantially higher than other sites (Fig. 9, Table 4). Hence the higher fluxes at Wytham relative to mainland Europe cannot simply be explained by climatic factors.

Only a few of these sites are not actively managed. Unmanaged forest sites in Fig. 9 include a 250 year-old temperate deciduous beech forest in central Germany with a carbon uptake of $4.9 \mathrm{MgC} \mathrm{ha}^{-1}$ (cumulative NEE: Knohl et al., 2003), a large uptake where the impacts of advection may have been underestimated according to Kutsch et al. (2008), thus possibly affecting the annual NEE. However, sequestration of this magnitude is supported by other research sites at beech forests around the globe (e.g. Valentini et al., 1996). An unmanaged mixed temperate forest in northeast China, parts of which are estimated to be greater than 450 years old, yielded an estimated carbon sink of around $2 \mathrm{MgC} \mathrm{ha}^{-1} \mathrm{yr}^{-1}$ (Guan et al., 2006), with vapour pressure deficits acting to restrict further carbon assimilation. Although NEP may decline with stand age (Ryan et al., 1997), mature temperate deciduous forests still have the potential to act as carbon sinks through natural regeneration, diversity of vegetation age and species turnover (Luyssaert et al., 2008) and possibly increased tree growth through $\mathrm{CO}_{2}$ fertilisation, earlier bud-break or increased nutrient availability.

The relatively large GPP estimates at Wytham and observed net sequestration of carbon may partially result from past management history. It is difficult to assess the degree to which the "ancient" sections of the forest are still adjusting to the influence of practices such as selective felling or coppicing which ceased 40 to 100 years ago (Gibson, 1986), but it is clear that the Woods are not in an equilibrium state even after 100 years. Such legacy effects are an important issue when calculating possible baselines and carbon stock changes under carbon forestry schemes (Böttcher et al., 
2008). In advanced unmanaged forest such as the ancient areas of Wytham small-scale disturbances such as windthrow, infestation, or fungal attack can facilitate new recruitment and thus biomass accumulation. Tree-falls caused by the storms of 1987 and 1990 are thought to have opened the canopy at Wytham, facilitating the growth of ash and sycamore in the gaps created (Kirby et al., 1996). Numbers of fallow deer (Dama dama L.) and Chinese muntjac (Muntiacus reevesi Ogilby) in the Woods have declined since populations boomed in the 1990s, due to regular culling (Mihok et al., 2009) and rabbit populations crashed following myxomatosis in the 1950s. Although reduced browsing pressure may have aided the regeneration of saplings and shrubs, evidence of slow recruitment (Mihok et al., 2009) suggests that established vegetation may account for almost all of the net carbon uptake in Wytham Woods. Atmospheric change factors, in particular $\mathrm{CO}_{2}$ fertilisation, warmer temperatures and nitrogen deposition may also contribute to the observed carbon sink but are difficult to tease apart from the management history influences.

\section{Conclusions}

The carbon budget of a temperate deciduous broadleaved forest has been estimated using two years of eddy covariance $\mathrm{CO}_{2}$ flux data. Variability in NEP appeared to be driven by changes in $R_{\mathrm{e}}$ resulting from seasonal fluctuations in weather conditions, whilst GPP was similar between years. At $21.1 \mathrm{MgCha}^{-1} \mathrm{yr}^{-1} \mathrm{GPP}$ was larger than thus far reported at other temperate deciduous forest sites. This is possibly a result of the UK's maritime climate (mild winters) and a negligible influence of water stress upon photosynthesis for the majority of the study period. Our eddy covariance estimates for both GPP and $R_{\mathrm{e}}$ are relatively closely matched with biometric and chamber data, increasing the confidence in the use of either technique to estimate carbon budgets. The Wytham Woods site was estimated to be a considerable carbon sink of $\sim 1.2 \mathrm{MgC} \mathrm{ha}^{-1} \mathrm{yr}^{-1}$ between May 2007 and April 2009. This estimate is validated by similar findings using stock-based measurements and is likely to be conservative since inclusion of low frequency turbulence results in greater estimated net carbon uptake.

Recent net sequestration of carbon may reflect the legacy of past management techniques at Wytham. The response of the terrestrial biosphere to projected future climates will determine the degree to which temperate deciduous forests can sequester future emissions. One could speculate that Wytham has the potential to be a larger carbon sink under projected warmer springs, especially with a potential " $\mathrm{CO}_{2}$ fertilisation effect". However, Broadmeadow et al. (2005) suggest that species such as oak and ash could be adversely affected by warmer summers, whereas sycamore may struggle to compete if droughts increase in frequency and magnitude (Morecroft et al., 2008). Continued research at sites such as Wytham will help build long term datasets to partition the effects of management, ecosystem dynamics (such as phenology and growing season length), environment $\left(\mathrm{CO}_{2}\right.$ fertilisation, nitrogen deposition) and climate change, upon terrestrial carbon budgets at forest sites.

\section{Appendix A}

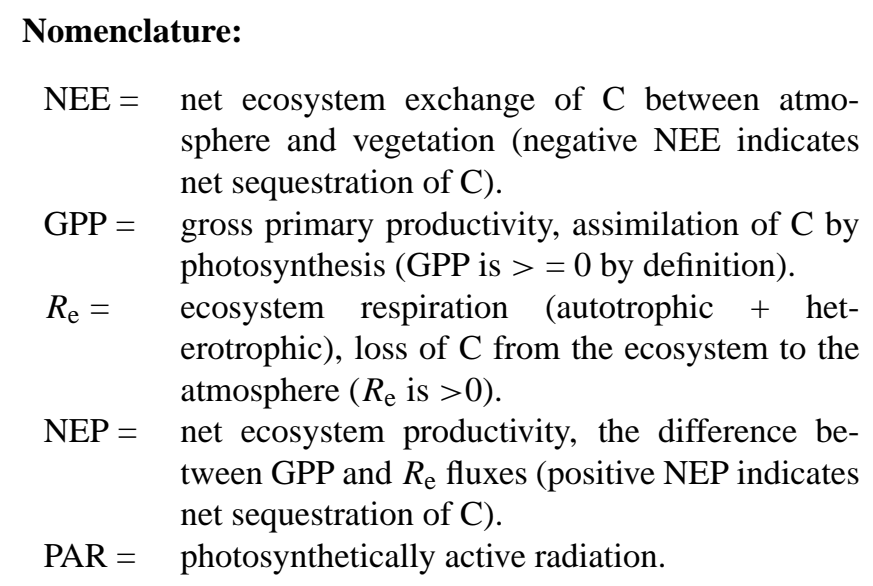

Acknowledgements. This study benefitted from the use of Robert Clement's advice and tips regarding the use of the data processing tool EdiRe. The authors are also grateful to CarboEurope for providing the free online gap-filling tool used in this study. Funding for MVT was provided by the Environmental Change Institute, School of Geography and the Environment, Oxford University; KMF was supported by a Natural Environment Research Council studentship; YM is supported by the Jackson Foundation. The establishment and operation of the flux tower and equipment were funded by the Centre for Ecology and Hydrology.

Edited by: R. Duursma 


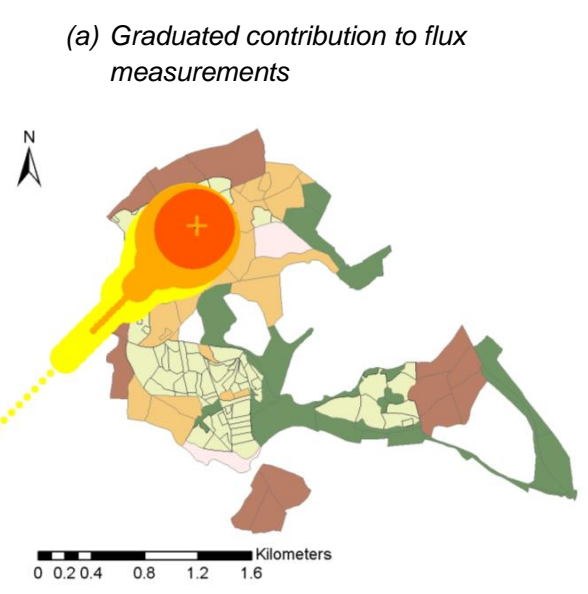
(b) Source area of flux measurements during very stable conditions

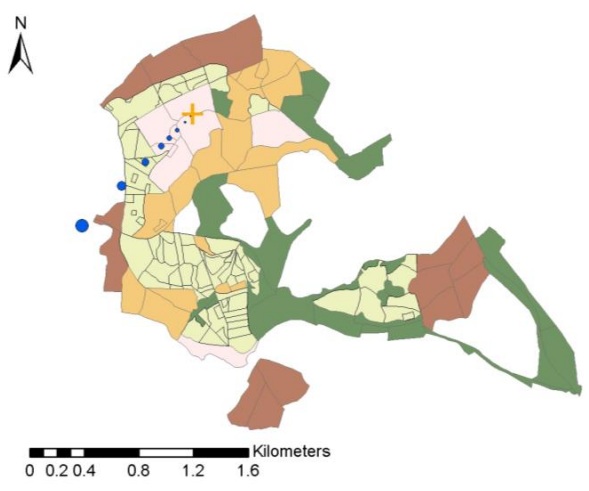

(c) Source area of flux measurements during moderate conditions
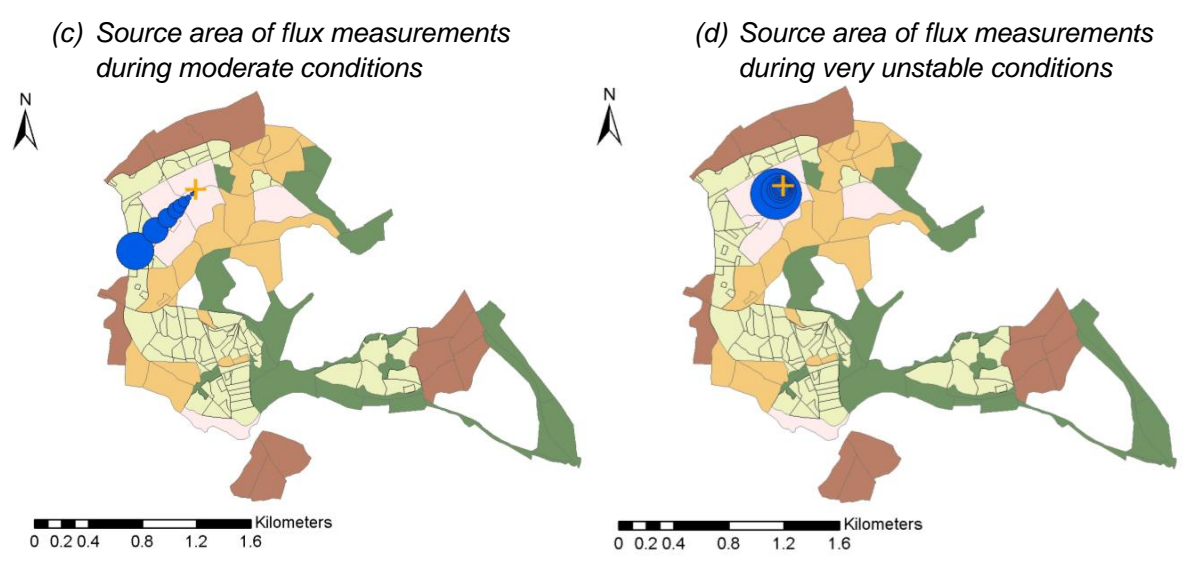

Fig. A1. Estimates of flux tower footprint. Colours in the graduated contribution to flux measurements (a, top left) represent atmospheric stability, whereby red $=$ very unstable $(Z \mathrm{~L}=-0.5 \mathrm{~m})$, orange $=$ moderate $(\mathrm{ZL}=-0.1 \mathrm{~m})$ and yellow $=$ very stable conditions $(\mathrm{ZL}=-0.001 \mathrm{~m})$. $\mathrm{ZL}$ = flux measurement height/Monin-Obukhov length (based on Schmid and Oke, 1990). Flux tower shown as cross and woodland type types as shown in Fig. 1.

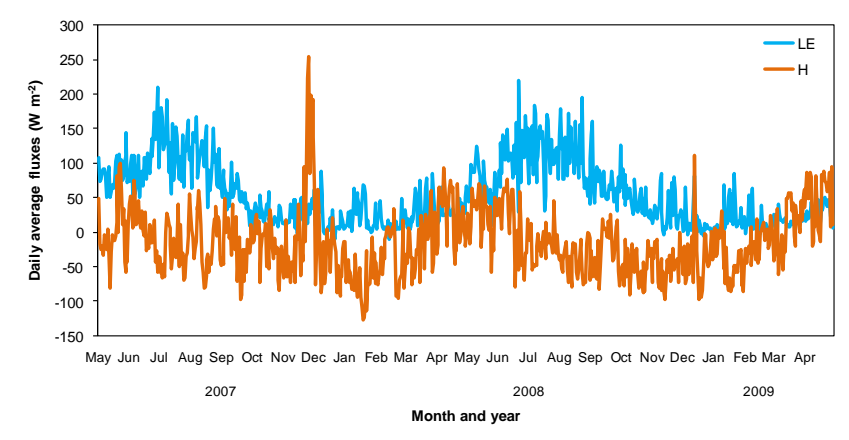

Fig. A2. Daily average fluxes of latent heat (LE) and sensible heat $(H)$ over the study period. Both units are $\mathrm{W} \mathrm{m}^{-2}$.

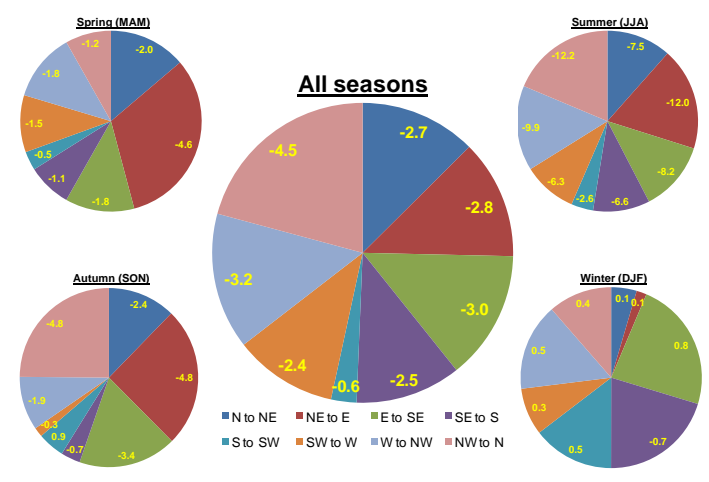

Fig. A3. Seasonal changes in average half-hourly $\mathrm{CO}_{2}$ flux grouped by wind direction. Larger segments represent greater half-hourly average $\mathrm{CO}_{2}$ flux detected from the corresponding wind direction and thus upwind vegetation. Total fluxes do not necessarily follow these seasonal patterns since wind direction is not evenly distributed: the prevailing direction is south-westerly. 


\section{References}

Amiro, B. D., Barr, A. G., Black, T. A., Iwashita, H., Kljun, N., McCaughey, J. H., Morgenstern, K., Murayama, S., Nesic, Z., Orchansky, A. L., and Saigusa, N.: Carbon, energy and water fluxes at mature and disturbed forest sites, Saskatchewan, Canada, Agr. Forest Meteorol., 136, 237-251, 2006.

Aubinet, M. and Feigenwinter, C.: Direct $\mathrm{CO}_{2}$ advection measurements and the night flux problem, Agr. Forest Meteorol., 150, 651-654, 2010.

Baldocchi, D.: TURNER REVIEW No. 15. "Breathing" of the terrestrial biosphere: lessons learned from a global network of carbon dioxide flux measurement systems, Aust. J. Bot., 56, 1-26, 2008.

Baldocchi, D. D., Black, T. A., Curtis, P. S., Falge, E., Fuentes, J. D., Granier, A., Gu, L., Knohl, A., Pilegaard, K., Schmid, H. P., Valentini, R., Wilson, K., Wofsy, S., Xu, L., and Yamamoto, S.: Predicting the onset of net carbon uptake by deciduous forests with soil temperature and climate data: a synthesis of FLUXNET data, Int. J. Biometeorol., 49, 377-387, 2005.

Baldocchi, D. D., Hincks, B. B., and Meyers, T. P.: Measuring Biosphere-Atmosphere Exchanges of Biologically Related Gases with Micrometeorological Methods, Ecology, 69, 13311340, 1988.

Baldocchi, D. and Valentini, R.: Geographic and temporal variation of the mechanisms controlling carbon exchange by ecosystems and their sensitivity to environmental perturbations, in: The global carbon cycle: integrating humans, climate and the natural world, edited by: Field, C. and Raupach, M., Island Press, Washington DC, 295-315, 2004.

Benham, S.: The Environmental Change Network at Alice Holt Research Forest, Forestry Commission, Edinburgh, 2008.

Broadmeadow, M. and Matthews, R.: Forests, Carbon and Climate Change: the UK Contribution, Forestry Commission, Edinburgh, 2003.

Broadmeadow, M. S. J., Ray, D., and Samuel, C. J. A.: Climate change and the future for broadleaved tree species in Britain, Forestry, 78, 145-161, 2005.

Bunce, R. G. H.: Biomass and Production of Trees in a Mixed Deciduous Woodland: I. Girth and Height as Parameters for the Estimation of Tree Dry Weight, J. Ecol., 56, 759-775, 1968.

Burba, G. G., McDermitt, D. K., Grelle, A., Anderson, D. J., and $\mathrm{Xu}, \mathrm{L}$.: Addressing the influence of instrument surface heat exchange on the measurements of $\mathrm{CO}_{2}$ flux from open-path gas analyzers, Glob. Change Biol., 14, 1854-1876, 2008.

Butt, N., Campbell, G., Malhi, Y., Morecroft, M., Fenn, K., and Thomas, M.: Initial results from establishment of a long-term broadleaf monitoring plot at Wytham Woods, Oxford, UK. University of Oxford Report, http://www.eci.ox.ac.uk/ publications/downloads/butt09-wythamwoods.pdf (Pdf downloaded on 25.11.2009), 2009.

Canadell, J. G., Le Quéré, C., Raupach, M. R., Field, C. B., Buitenhuis, E. T., Ciais, P., Conway, T. J., Gillett, N. P., Houghton, R. A., and Marland, G.: Contributions to accelerating atmospheric $\mathrm{CO}_{2}$ growth from economic activity, carbon intensity, and efficiency of natural sinks, P. Natl. Acad. Sci., 104, 47, 1886618870, 2007.

Carrara, A., Janssens, I. A., Curiel Yuste, J., and Ceulemans, R.: Seasonal changes in photosynthesis, respiration and NEE of a mixed temperate forest, Agr. Forest Meteorol., 126, 15-31, 2004.
Ciais, P., Reichstein, M., Viovy, N., Granier, A., Ogee, J., Allard, V., Aubinet, M., Buchmann, N., Bernhofer, C., Carrara, A., Chevallier, F., De Noblet, N., Friend, A. D., Friedlingstein, P., Grunwald, T., Heinesch, B., Keronen, P., Knohl, A., Krinner, G., Loustau, D., Manca, G., Matteucci, G., Miglietta, F., Ourcival, J. M., Papale, D., Pilegaard, K., Rambal, S., Seufert, G., Soussana, J. F., Sanz, M. J., Schulze, E. D., Vesala, T., and Valentini, R.: Europe-wide reduction in primary productivity caused by the heat and drought in 2003, Nature, 437, 529-533, 2005.

Clement, R.: Mass and Energy Exchange of a Plantation Forest in Scotland Using Micrometeorological Methods, PhD, Geosciences, University of Edinburgh, Edinburgh, 2004.

Curtis, P. S., Hanson, P. J., Bolstad, P., Barford, C., Randolph, J. C., Schmid, H. P., and Wilson, K. B.: Biometric and eddycovariance based estimates of annual carbon storage in five eastern North American deciduous forests, Agr. Forest Meteorol., 113, 3-19, 2002.

Defra: A Strategy for England's Trees, Woods and Forests, Department for Environment, Food and Rural Affairs, London, 2007.

Delpierre, N., Soudani, K., Francois, C., Köstner, B., Pontailler, J. Y., Nikinmaa, E., Misson, L., Aubinet, M., Bernhofer, C., Granier, A., Grünwald, T., Heinesch, B., Longdoz, B., Ourcival, J. M., Rambal, S., Vesala, T., and Dufrêne, E.: Exceptional carbon uptake in European forests during the warm spring of 2007 : a data model analysis, Glob. Change Biol., 15, 1455-1474, 2009.

Farquhar, G. D., Caemmerer, S., and Berry, J. A.: A biochemical model of photosynthetic $\mathrm{CO}_{2}$ assimilation in leaves of $\mathrm{C} 3$ species, Planta, 149, 78-90, 1980.

Fenn, K.: PhD Thesis, Environmental Change Institute, School of Geography and the Environment, Oxford University, 2010.

Fenn, K., Malhi, Y., Morecroft, M., Lloyd, C., Thomas, M., and McNeil, D.: Comprehensive description of the carbon cycle of an ancient temperate broadleaved woodland, submitted, 2011.

Fenn, K., Malhi, Y., and Morecroft, M.: Soil $\mathrm{CO}_{2}$ efflux in a temperate deciduous forest: environmental drivers and component contributions, Soil. Biol. Biochem., 42, 1685-1693, 2010.

Gibson, C. W. D.: Management history in relation to changes in the flora of different habitats on an Oxfordshire Estate, England, Biol. Conserv., 38, 217-232, 1986.

Goulden, M. L., Munger, J. W., Fan, S.-M., Daube, B. C., and Wofsy, S. C.: Measurements of carbon sequestration by longterm eddy covariance: methods and a critical evaluation of accuracy, Glob. Change Biol., 2, 169-182, 1996.

Granier, A., Ceschia, E., Damesin, C., Dufrêne, E., Epron, D., Gross, P., Lebaube, S., Dantec, V. L., Goff, N. L., Lemoine, D., Lucot, E., Ottorini, J. M., Pontailler, J. Y., and Saugier, B.: The carbon balance of a young Beech forest, Funct. Ecol., 14, 312325, 2000.

Guan, D.-X., Wu, J.-B., Zhao, X.-S., Han, S.-J., Yu, G.-R., Sun, X.-M., and Jin, C.-J.: $\mathrm{CO}_{2}$ fluxes over an old, temperate mixed forest in northeastern China, Agr. Forest Meteorol., 137, 138149, 2006.

Hirata, R., Hirano, T., Saigusa, N., Fujinuma, Y., Inukai, K., Kitamori, Y., Takahashi, Y., and Yamamoto, S.: Seasonal and interannual variations in carbon dioxide exchange of a temperate larch forest, Agr. Forest Meteorol., 147, 110-124, 2007.

Huxman, T. E., Snyder, K. A., Tissue, D., Leffler, A. J., Ogle, K., Pockman, W. T., Sandquist, D. R., Potts, D. L., and Schwinning, S.: Precipitation pulses and carbon fluxes in semiarid and arid 
ecosystems, Oecologia, 141, 254-268, 2004.

Jackson, R. B., Canadell, J., Ehleringer, J. R., Mooney, H. A., Sala, O. E., and Schulze, E. D.: A global analysis of root distributions for terrestrial biomes, Oecologia, 108, 389-411, 1996.

Janssens, I. A., Freibauer, A., Ciais, P., Smith, P., Nabuurs, G.-J., Folberth, G., Schlamadinger, B., Hutjes, R. W. A., Ceulemans, R., Schulze, E.-D., Valentini, R., and Dolman, A. J.: Europe's Terrestrial Biosphere Absorbs 7 to $12 \%$ of European Anthropogenic $\mathrm{CO}_{2}$ Emissions, Science, 300, 1538-1542, 2003.

Jarvis, P. G., Morison, J. I. L., Chaloner, W. G., Cannell, M. G. R., Roberts, J., Jones, H. G., and Amtmann, R.: Atmospheric Carbon Dioxide and Forests [and Discussion], Philos. T. Roy. Soc. B., 324, 369-392, 1989.

Kirby, K. J., Thomas, R. C., and Dawkins, H. C.: Monitoring of changes in tree and shrub layers in Wytham Woods (Oxfordshire), 1974-1991, Forestry, 69, 319-334, 1996.

Knohl, A., Schulze, E.-D., Kolle, O., and Buchmann, N.: Large carbon uptake by an unmanaged 250-year-old deciduous forest in Central Germany, Agr. Forest Meteorol., 118, 151-167, 2003.

Kominami, Y., Jomura, M., Dannoura, M., Goto, Y., Tamai, K., Miyama, T., Kanazawa, Y., Kaneko, S., Okumura, M., Misawa, N., Hamada, S., Sasaki, T., Kimura, H., and Ohtani, Y.: Biometric and eddy-covariance-based estimates of carbon balance for a warm-temperate mixed forest in Japan, Agr. Forest Meteorol., 148, 723-737, 2008.

Kutsch, W. L., Liu, C., Hörmann, G., and Herbst, M.: Spatial heterogeneity of ecosystem carbon fluxes in a broadleaved forest in northern Germany, Glob. Change Biol., 11, 70-88, 2005.

Kutsch, W. L., Kolle, O., Rebmann, C., Knohl, A., Ziegler, W., and Schulze, E.-D.: Advection and resulting $\mathrm{CO}_{2}$ exchange uncertainty in a tall forest in central Germany, Ecol. Appl., 18, 13911405, 2008.

Lee, X., Fuentes, J. D., Staebler, R. M., and Neumann, H. H.: Longterm observation of the atmospheric exchange of $\mathrm{CO}_{2}$ with a temperate deciduous forest in southern Ontario, Canada, J. Geophys. Res., 104, 15975-15984, 1999.

Lloyd, C. R.: Annual carbon balance of a managed wetland meadow in the Somerset Levels, UK, Agr. Forest Meteorol., 138, 168-179, 2006.

Lloyd, J. and Taylor, J. A.: On the Temperature Dependence of Soil Respiration, Funct. Ecol., 8, 315-323, 1994.

Luyssaert, S., Inglima, I., Jung, M., Richardson, A. D., Reichstein, M., Papale, D., Paio, S. L., Schulze, E.-D., Wingate, L., Matteucci, G., Aragao, L., Aubinet, M., Beer, C., Bernhofer, C., Black, K. G., Bonal, D., Bonnefond, J.-M., Chambers, J., Ciais, P., Cook, B., Davis, K. J., Dolman, A. J., Gielen, B., Goulden, M., Grace, J., Granier, A., Grelle, A., Griffis, T., Grunwald, T., Guidolotti, G., Hanson, P. J., Harding, R., Hollinger, D. Y., Hutyra, L. R., Kolari, P., Kruijt, B., Kutsch, W., Lagergren, F., Laurila, T., Law, B. E., Maire, G. L., Lindroth, A., Loustau, D., Malhi, Y., Mateus, J., Migliavacca, M., Misson, L., Montagnani, L., Moncrieff, J., Moors, E., Munger, J. W., Nikinmaa, E., Ollinger, S. V., Pita, G., Rebmann, C., Roupsard, O., Saigusa, N., Sanz, M. J., Seufert, G., Sierra, C., Smith, M.-L., Tang, J., Valentini, R., Vesala, T., and Janssens, I. A.: $\mathrm{CO}_{2}$ balance of boreal, temperate, and tropical forests derived from a global database, Glob. Change Biol., 13, 2509-2537, 2007.

Luyssaert, S., Schulze, E. D., Borner, A., Knohl, A., Hessenmoller, D., Law, B. E., Ciais, P., and Grace, J.: Old-growth forests as global carbon sinks, Nature, 455, 213-215, 2008.

Malhi, Y., McNaughton, K., and Von Randow, C.: Low Frequency Atmospheric Transport and Surface Flux Measurements, in: Handbook of Micrometeorology: A Guide for Surface Flux Measurement and Analysis, edited by: Lee, X., Massman, W. J., and Law, B., Kluwer, Dordrecht, 2004.

Mihok, B., Kenderes, K., Kirby, K. J., Paviour-Smith, K., and Elbourn, C. A.: Forty-year changes in the canopy and the understorey in Wytham Woods, Forestry, 82(5), 515-527 cpp021, doi:10.1093/forestry/cpp021, 2009.

Misson, L., Baldocchi, D. D., Black, T. A., Blanken, P. D., Brunet, Y., Curiel Yuste, J., Dorsey, J. R., Falk, M., Granier, A., Irvine, M. R., Jarosz, N., Lamaud, E., Launiainen, S., Law, B. E., Longdoz, B., Loustau, D., McKay, M., Paw U, K. T., Vesala, T., Vickers, D., Wilson, K. B., and Goldstein, A. H.: Partitioning forest carbon fluxes with overstory and understory eddy-covariance measurements: A synthesis based on FLUXNET data, Agr. Forest Meteorol., 144, 14-31, 2007.

Moffat, A. M., Papale, D., Reichstein, M., Hollinger, D. Y., Richardson, A. D., Barr, A. G., Beckstein, C., Braswell, B. H., Churkina, G., Desai, A. R., Falge, E., Gove, J. H., Heimann, M., Hui, D., Jarvis, A. J., Kattge, J., Noormets, A., and Stauch, V. J.: Comprehensive comparison of gap-filling techniques for eddy covariance net carbon fluxes, Agr. Forest Meteorol., 147, 209-232, 2007.

Moncrieff, J. B., Malhi, Y., and Leuning, R.: The propagation of errors in long-term measurements of land-atmosphere fluxes of carbon and water, Glob. Change Biol., 2, 231-240, 1996.

Morecroft, M. D. and Roberts, J. M.: Photosynthesis and stomatal conductance of mature canopy Oak (Quercus robur) and Sycamore (Acer pseudoplatanus) trees throughout the growing season, Funct. Ecol., 13, 332-342, 1999.

Morecroft, M. D., Stokes, V. J., and Morison, J. I. L.: Seasonal changes in the photosynthetic capacity of canopy oak (Quercus robur) leaves: the impact of slow development on annual carbon uptake, Int. J. Biometeorol., 47, 221-226, 2003.

Morecroft, M. D., Stokes, V. J., Taylor, M. E., and Morison, J. I. L.: Effects of climate and management history on the distribution and growth of sycamore (Acer pseudoplatanus L.) in a southern British woodland in comparison to native competitors, Forestry, 81, 59-74, 2008.

Morecroft, M. D., Taylor, M. E., and Oliver, H. R.: Air and soil microclimates of a deciduous woodland compared to an open site, Agr. Forest Meteorol., 90, 141-156, 1998.

Nakai, T., van der Molen, M. K., Gash, J. H. C., and Kodama, Y.: Correction of sonic anemometer angle of attack errors, Agr. Forest Meteorol., 136, 19-30, 2006.

Papale, D., Reichstein, M., Aubinet, M., Canfora, E., Bernhofer, C., Kutsch, W., Longdoz, B., Rambal, S., Valentini, R., Vesala, T., and Yakir, D.: Towards a standardized processing of Net Ecosystem Exchange measured with eddy covariance technique: algorithms and uncertainty estimation, Biogeosciences, 3, 571-583, doi:10.5194/bg-3-571-2006, 2006.

Paw U, K. T., Falk, M., Suchanek, T. H., Ustin, S. L., Chen, J., Park, Y.-S., Winner, W. E., Thomas, S. C., Hsiao, T. C., Shaw, R. H., King, T. S., Pyles, R. D., Schroeder, M., and Matista, A. A.: Carbon Dioxide Exchange Between an Old-growth Forest and the Atmosphere, Ecosystems, 7, 513-524, 2004.

Peterken, G. F.: Woodland Conservation and Management, Chap- 
man and Hall, London, 1981.

Pilegaard, K., Hummelshøj, P., Jensen, N. O., and Chen, Z.: Two years of continuous $\mathrm{CO}_{2}$ eddy-flux measurements over a Danish beech forest, Agr. Forest Meteorol., 107, 29-41, 2001.

Read, D. J., Freer-Smith, P. H., Morison, J. I. L., Hanley, N., West, C. C., and Snowdon, P.: Combating climate change - a role for UK forests. An assessment of the potential of the UK's trees and woodlands to mitigate and adapt to climate change. The synthesis report, The Stationery Office, Edinburgh, 2009.

Reichstein, M., Falge, E., Baldocchi, D., Papale, D., Aubinet, M., Berbigier, P., Bernhofer, C., Buchmann, N., Gilmanov, T., Granier, A., Grünwald, T., Havránková, K., Ilvesniemi, H., Janous, D., Knohl, A., Laurila, T., Lohila, A., Loustau, D., Matteucci, G., Meyers, T., Miglietta, F., Ourcival, J.-M., Pumpanen, J., Rambal, S., Rotenberg, E., Sanz, M., Tenhunen, J., Seufert, G., Vaccari, F., Vesala, T., Yakir, D., and Valentini, R.: On the separation of net ecosystem exchange into assimilation and ecosystem respiration: review and improved algorithm, Glob. Change Biol., 11, 1424-1439, 2005.

Rodwell, J. S.: British Plant Communities, Volume 1: Woodlands and Scrub, Cambridge University Press, Cambridge, 1991.

Ryan, M. G., Binkley, D., and Fownes, J. H.: Age-related decline in forest productivity: pattern and process, Adv. Ecol. Res., 27, 213-262, 1997.

Saigusa, N., Yamamoto, S., Hirata, R., Ohtani, Y., Ide, R., Asanuma, J., Gamo, M., Hirano, T., Kondo, H., Kosugi, Y., Li, S.-G., Nakai, Y., Takagi, K., Tani, M., and Wang, H.: Temporal and spatial variations in the seasonal patterns of $\mathrm{CO}_{2}$ flux in boreal, temperate, and tropical forests in East Asia, Agr. Forest Meteorol., 148, 700-713, 2008.

Savill, P. S., Perrins, C. M., Kirby, K. J., and Fisher, N.: Wytham Woods: Oxford's Ecological Laboratory. Oxford University Press, Oxford, 2010.

Schmid, H. P. and Oke, T. R.: A model to estimate the source area contributing to turbulent exchange in the surface layer over patchy terrain, Q. J. Roy. Meteor. Soc., 116, 965-988, 1990.

Urbanski, S., Barford, C., Wofsy, S., Kucharik, C., Pyle, E., Budney, J., McKain, K., Fitzjarrald, D., Czikowsky, M., and Munger, J. W.: Factors controlling $\mathrm{CO}_{2}$ exchange on timescales from hourly to decadal at Harvard Forest, J. Geophys. Res., 112, doi:10.1029/2006jg000293, 2007.
Valentini, R., Angelis, P., Matteucci, G., Monaco, R., Dore, S., and Mucnozza, G. E. S.: Seasonal net carbon dioxide exchange of a beech forest with the atmosphere, Glob. Change Biol., 2, 199207, 1996.

Valentini, R., Matteucci, G., Dolman, A. J., Schulze, E. D., Rebmann, C., Moors, E. J., Granier, A., Gross, P., Jensen, N. O., Pilegaard, K., Lindroth, A., Grelle, A., Bernhofer, C., Grunwald, T., Aubinet, M., Ceulemans, R., Kowalski, A. S., Vesala, T., Rannik, U., Berbigier, P., Loustau, D., Gumundsson, J., Thorgeirsson, H., Ibrom, A., Morgenstern, K., Clement, R., Moncrieff, J., Montagnani, L., Minerbi, S., and Jarvis, P. G.: Respiration as the main determinant of carbon balance in European forests, Nature, 404, 861-865, 2000.

van der Werf, G. R., Morton, D. C., DeFries, R. S., Olivier, J. G. J., Kasibhatla, P. S., Jackson, R. B., Collatz, G. J., and Randerson, J. T.: $\mathrm{CO}_{2}$ emissions from forest loss, Nat. Geosci, 2, 737-738, 2009.

van Gorsel, E., Delpierre, N., Leuning, R., Black, A., Munger, W., Wofsy, S., Aubinet, M., Feigenwinter, C., Beringer, J., Bonal, D., Chen, B., Chen, J., Clement, R., Davis, K. J., Desai, A. R., Dragoni, D., Etzold, S., Grünwald, T., Gu, L., Heinesch, B., Hutyra, L.R., Jans, W. W. P., Kutsch, W., Law, B. E., Leclerc, M. Y., Mammarella, I., Montagnani, L., Noormets, A., Rebmann, C., and Wharton, S.: Estimating nocturnal ecosystem respiration from the vertical turbulent flux and change in storage of $\mathrm{CO}_{2}$, Agr. Forest Meteorol., 149, 1919-1930, 2009.

Webb, E. K., Pearman, G. I., and Leuning, R.: Correction of flux measurements for density effects due to heat and water vapour transfer, Q. J. Roy. Meteor. Soc., 106, 85-100, 1980.

Weiss, A. and Norman, J. M.: Partitioning solar radiation into direct and diffuse, visible and near-infrared components, Agr. Forest Meteorol., 34, 205-213, 1985.

Wirth, C., Czimczik, C. I., and Schulze, E.-D.: Beyond annual budgets: carbon flux at different temporal scales in fire-prone Siberian Scots pine forests, Tellus B, 54, 611-630, 2002.

Zhang, J.-H., Han, S.-J., and Yu, G.-R.: Seasonal variation in carbon dioxide exchange over a 200-year-old Chinese broad-leaved Korean pine mixed forest, Agr. Forest Meteorol., 137, 150-165, 2006. 